\title{
Policymakers' Horizon and Trade Reforms: The Protectionist Effect of Elections*
}

\author{
Paola Conconi \\ Université Libre de Bruxelles (ECARES) and CEPR
}

\author{
Giovanni Facchini \\ University of Nottingham, Universitá di Milano, CEPR and CES-Ifo
}

Maurizio Zanardi

Lancaster University Management School

June 2014

\begin{abstract}
This paper shows that electoral incentives deter politicians from supporting trade liberalization. We focus on all major trade liberalization bills introduced since the early 1970s in the U.S. Congress, in which House and Senate members serve respectively two- and six-year terms and one third of senators face elections every two years. We show that senators are more likely to support trade liberalization than House representatives. However, this result does not hold for the last generation of senators, who face elections at the same time as House members, suggesting that inter-cameral differences are driven by term length. Considering senators alone, we find that the last generation is less likely to support trade liberalization than the previous two. This result is pervasive and holds both when comparing the behavior of different senators voting on the same bill and that of individual senators voting on different bills. The protectionist effect of election proximity disappears for senators who are retiring or hold safe seats.
\end{abstract}

JEL classifications: D72, F10.

Keywords: Term length, election proximity, roll-call votes, trade liberalization.

\footnotetext{
*We are grateful to Alberto Alesina, Richard Baldwin, Bruce Blonigen, Ernesto Dal Bo, Thad Dunning, Mathias Dewatripont, Jeff Frieden, Gene Grossman, Keith Head, Nuno Limão, Giovanni Maggi, Thierry Mayer, John McLaren, Carlo Perroni, Torsten Persson, Steve Redding, Bob Staiger, Daniel Sturm, Alessandro Turrini, Thierry Verdier, and two anonymous referees for their valuable suggestions. We also wish to thank for their comments participants at the Harvard Faculty Discussion Group on Political Economy, the Leitner Political Economy Seminar at Yale University, the CEPR ERWIT meeting in Madrid, the workshop on New Political Economy of Trade at EUI, the CEPR workshop on Politics, Information and the Macroeconomy at CREI, the FREIT conference in Calgary, the workshop on Trade Policy in a Globalised World in Venice, the NBER Summer Institute on Political Economy, and seminar audiences at Boston University, the Institute for Advanced Studies in Vienna, Trinity College Dublin, Nottingham University, Seoul National University, CORE, ECARES, ETH Zurich, the Graduate Institute in Geneva, and the Paris School of Economics. We are grateful to Lauren Bell, Alexandra Guisinger, Christopher Magee, and James Snyder for help with the data. We are also indebted to Silvia Cerisola, Elena Mattevi, and Christian Wolf for excellent research assistance. Research funding from the FNRS and the European Commission (PEGGED and GRASP projects) is gratefully acknowledged. Correspondence to Paola Conconi, ECARES, Université Libre de Bruxelles, Avenue Roosevelt 50, 1050 Brussels, Belgium; email: pconconi@ulb.ac.be.
} 


\section{Introduction}

As pointed out by Rodrik (1995), "no other area of economics displays such a gap between what policymakers practice and what economists preach as does international trade." Why do policymakers often fail to support trade liberalization, favoring instead protectionist policies?

Anecdotal evidence suggests that electoral incentives play a key role in answering this question. For instance, during his first presidential campaign in 2008, Barack Obama was accused of pandering to the protectionist sentiments of blue-collar workers when he attacked the North American Free Trade Agreement (NAFTA) as being "devastating on the community" and stated "I don't think NAFTA has been good for America, and I never have". He later admitted that his campaign rhetoric had been "overheated and amplified", stressing that "politicians are always guilty of that, and I don't exempt myself". ${ }^{1}$

In this paper, we provide systematic evidence that electoral incentives lead politicians to take a protectionist stance. In particular, we show that the political horizon of U.S. congressmen the length of their terms in office and how close they are to facing elections - crucially affects their support for trade liberalization reforms. The focus on the United States is not only due to the availability of roll-call votes, but also to the specific institutional features of the U.S. Congress, in which House and Senate representatives serve respectively two- and six-year terms, and one third of the Senate is up for re-election every two years. Inter-cameral differences in term length and the staggered structure of the Senate make the U.S. Congress an ideal setting to understand how policymakers' horizon shapes their trade policy decisions: at any point in time, it is possible to compare the voting behavior of legislators with mandates of different length, as well as the behavior of senators belonging to different "generations", i.e. facing elections at different times. ${ }^{2}$ Exploiting the fact that many senators cast multiple votes on trade reforms, we can also study whether election proximity affects the stance of individual legislators during their terms in office. ${ }^{3}$

To carry out our analysis, we collect data on individual roll-call votes on trade liberalization bills introduced in the U.S. Congress since the early 1970s. These include the ratification and implementation of multilateral trade agreements (Tokyo and Uruguay Round of the GATT) and

\footnotetext{
${ }^{1}$ See the article "Obama: NAFTA not so bad after all," Fortune, June 18, 2008. Similarly, in 2012, less than two months before facing re-election, and the same day he was campaigning in the crucial swing state of Ohio, President Obama lodged a complaint against China at the World Trade Organization, alleging that it unfairly subsidizes car-part exports. "There was nothing subtle about (the timing of the complaint) - but then subtlety does not win many elections" (The Economist, "Chasing the anti-China vote: a suspiciously timed dispute", September 22, 2012). Presidential candidate Mitt Romney responded by pledging that, if elected, he would crack down on unfair trade practices (Los Angeles Times, "In Ohio, Obama and Romney fight over China, trade", September 26, 2012).

${ }^{2}$ In most other countries, even if legislators belonging to the lower and upper house serve terms of different lengths, members of the same house face elections at the same time (e.g. Australia and France). An interesting exception is Argentina, in which both houses of the Congreso Nacional have a staggered structure.

${ }^{3}$ For example, during her first mandate as senator from New York state, Hillary Clinton voted on six trade liberalization bills, four times in favor (during the first four years) and twice against (during the last two years).
} 
preferential trade agreements (e.g. the Canada-United States Free Trade Agreement, NAFTA) negotiated during this period, as well as the conferral and extension of fast track trade negotiating authority to the President. We have complemented this data with information on many characteristics of the legislators and their constituencies, covering both economic and non-economic drivers of individual voting decisions on trade reforms.

We compare first the voting behavior of House and Senate members. In line with previous studies, we show that senators are more likely to support trade liberalization than House representatives. Crucially, however, we find no significant difference between House members and the last generation of senators, two groups of legislators who are up for re-election at the same time. This result provides an explanation for the observed inter-cameral differences in trade policy votes. Some scholars have argued that senators are less protectionist than House members because they represent larger constituencies (e.g. Magee, Brock, and Young 1989); however, as already pointed out by Karol (2007), constituency size is actually unrelated to congressmen's votes on trade and cannot explain inter-cameral differences. Our analysis suggests that these are instead driven by differences in term length: senators are generally more supportive of trade liberalization because they serve longer mandates; as they approach the end of their terms, they become as protectionist as House members.

We then focus on the role of election proximity, comparing the voting behavior of different generations of senators. We find that the last generation is significantly more protectionist than the previous two. The effect is sizable: members of the Senate who are in the last two years of their mandates are around 10 percentage points less likely to support trade liberalization than senators in the first four years. The results continue to hold when - rather than comparing different individuals voting on the same bill - we study the behavior of the same individual over time. Inter-generational differences are also robust to including a wealth of controls for legislators (e.g. party affiliation and whether it is the same as the executive's, age, gender, campaign contributions received from labor and corporate groups) and their constituencies (e.g. employment in export/import-competing industries, percentage of high skilled workers, size), focusing on different subsets of trade reforms, and using alternative econometric methodologies. The protectionist effect of election proximity is pervasive: even senators representing export constituencies, in which a majority of the electorate should gain from trade liberalization, become significantly more protectionist at the end of their terms.

To verify whether inter-generational differences are driven by electoral incentives, we carry out two falsification exercises, focusing on senators who are retiring (i.e. have announced that they will not stand for re-election) or hold safe seats (i.e. have been elected with a large margin of victory). We find that election proximity has no impact on the voting behavior of these legislators, suggesting that re-election motives are the key reason behind the cyclical behavior observed among U.S. senators at large. 
The observed patterns in the voting behavior of Congress members cannot be readily explained by existing models in the literature on the political economy of trade policy, which do not consider the role of term length and electoral calendars. Our findings suggest that reelection motives deter politicians from supporting trade liberalization reforms and that this effect is stronger at the end of their terms, when their policy decisions have a bigger impact on their chances to retain office.

The remainder of the paper is organized as follows. Section 2 briefly reviews the related literature. Section 3 describes the dataset and variables used in our analysis. Section 4 examines the role of term length, comparing the voting behavior of House and Senate members. Section 5 focuses on the effect of election proximity, comparing the voting behavior of different generations of senators. Section 6 discusses possible mechanisms behind our empirical findings. Section 7 concludes, pointing to avenues for future research.

\section{Related literature}

Our paper is related to several strands of the literature. First, it contributes to the analysis of the political economy of trade policy. Several studies have focused on voting and elections (e.g. Mayer 1984; Baldwin 1989; Magee, Brock, and Young 1989; Dutt and Mitra 2002; Grossman and Helpman 2005). Much attention has also been devoted to the role of lobby groups (e.g. Grossman and Helpman 1994; Grossman and Helpman 1995, Goldberg and Maggi 1999; Mitra 1999; Gawande and Bandyopadhyay 2000; Mitra, Thomakos, and Ulubaşoğlu 2002). Other studies have focused on different political factors, such as governments' inability to commit to policy choices (Maggi and Rodriguez-Clare 1998) or ratification rules (Conconi, Facchini, and Zanardi 2012). This is the first paper to emphasize the importance of term length and election proximity.

Our analysis builds also on a large body of work that has studied the political economy obstacles to the adoption of economic reforms, i.e. major policy changes that go beyond regular government decisions, including structural reforms (e.g. trade or labor market liberalization) and stabilization reforms (e.g. important fiscal adjustments to drastically reduce budget deficits and/or inflation). One of the seminal contributions in this area is the paper by Fernandez and Rodrik (1991), which shows that uncertainty about who will enjoy the gains from trade liberalization can lead a rational electorate to oppose a reform ex ante, even when welfare is known to increase ex post for a majority. Several other papers have examined the political viability of economic reforms in the presence of distributional effects and uncertainty. For example, Alesina and Drazen (1991) show how a stabilization can be delayed due to a "war of attrition" between two groups, each of which is uncertain about the costs being incurred by the other. Dewatripont and Roland (1995) introduce instead aggregate uncertainty in the framework of Fernandez and 
Rodrik (1991) to analyze the optimal sequencing of economic reforms. None of these papers has examined the role of legislators' political horizon, which is the focus of our analysis.

Our work is also related to the literature on political business cycles, which emphasizes the importance of electoral calendars when politicians are office motivated. Close to election, incumbent politicians manipulate regular government decisions on fiscal and monetary policies to signal their competence (Rogoff and Sibert 1988; Rogoff 1990). Our paper shows that electoral calendars crucially affect legislators' choices on trade liberalization reforms.

Our empirical strategy builds on a vast political science literature that analyzes the effects of term length and election proximity on legislative behavior. Rather than studying the determinants of legislators' behavior on specific economic reforms such as trade liberalization, these studies focus on "voting scores", summary indexes of their voting record on a broad set of issues (e.g. ADA scores, D-Nominate and W-Nominate scores). Some papers in this tradition analyze how election proximity affects senators' ideological positions (e.g. Thomas 1985, Bernhard and Sala 2006). Other papers examine instead the effects of election proximity on senators' responsiveness to the desires of the polity (e.g. Amacher and Boyes 1978, Glazer and Robbins 1985, Levitt 1996). These studies compare senators' voting scores to measures of their constituencies' preferences and find that, while there are considerable discrepancies between the two, the gap gets smaller closer to elections. Two recent contributions, Titiunik (2008) and Dal Bo and Rossi (2011) use instead an experimental setting to study the effect of different term lengths on legislator's performance. ${ }^{4}$

Finally, our paper is related to the empirical literature examining the determinants of the voting behavior of U.S. congressmen on specific economic policies. The pioneering contribution by Peltzman (1985) links senators' voting patterns on federal tax and spending with changes in the economic interests of their constituencies. ${ }^{5}$ Only a few studies have examined the determinants of trade policy votes, focusing on the role of direct foreign investments and campaign contributions by lobby groups (Blonigen and Figlio 1998, Baldwin and Magee 2000).

\section{Data}

To carry out our analysis, we have assembled a novel dataset that allows us to link congressmen's voting behavior on a trade liberalization bill to a wealth of characteristics of the legislators and

\footnotetext{
${ }^{4}$ Titiunik (2008) examines the effect of a randomly assigned term length on the behavior of a small group of state senators in Arkansas and Texas. Dal Bo and Rossi (2011) consider two natural experiments in the Argentine legislature (in 1983 and 2001), when politicians were assigned different term lengths through a randomized procedure. Both papers reach the conclusion that longer terms in office lead to better performance (for instance in terms of floor attendance, or number of bills sponsored by a legislator).

${ }^{5}$ More recent contributions include Mian, Sufi, and Trebbi (2010), who investigate how constituencies' interests, lobbying, and politicians' ideology shape voting on two bills introduced in the aftermath of the recent financial crisis, and Facchini and Steinhardt (2011), who examine the determinants of voting behavior on U.S. immigration policy in the last four decades.
} 
their constituencies. This enables us to investigate the role played by both economic and noneconomic drivers of individual decisions. In this section, we describe our data, starting from our dependent variable. We discuss next the individual-level characteristics, and finally turn to the procedure we have followed to construct our constituency-level controls.

\subsection{Votes on trade reforms}

Our analysis focuses on recorded (roll-call) final passage votes on all major trade liberalization bills introduced in the U.S. Congress between 1973 and 2005. By looking at final passage votes, we exclude votes on amendments and other intermediate procedural steps from our analysis. We have decided to follow this strategy because the expectations on the effects of floor amendments are less clear cut than for final passage votes. Voting on amendments is often strategic and is therefore less likely to distinctly reflect the interests of the legislator's constituency (Poole and Rosenthal 1997).

Table A-1 in the Appendix lists the bills included in our analysis, which cover the implementation of multilateral trade agreements (Tokyo and Uruguay Round rounds of the GATT) and preferential trade agreements negotiated in this period, ${ }^{6}$ as well as the initiatives to confer or extend fast track trade negotiating authority to the President. ${ }^{7}$

We distinguish between the 50 U.S. states - electing each two representatives for the Senate and the 435 congressional districts - each electing one member of the House of Representatives. ${ }^{8}$ Overall, we consider 29 votes. ${ }^{9}$ For each of them, we collect the identity of the congressmen, their state or district, and their decision (in favor or against) from roll-call records. In our benchmark analysis, we include all the trade bills in our sample, but we assess the robustness of our findings by focusing on different subsets of bills (see Section 4.3).

\subsection{Characteristics of legislators}

Table A-2 in the Appendix provides definitions and sources for all the variables included as controls in our analysis of trade liberalization votes (top panel), or used in the construction of

\footnotetext{
${ }^{6}$ We excluded the bills on the ratification of the US-Bahrain and US-Israel free trade agreements, which were approved by voice votes in at least one of the houses. We also excluded all the bills to extend most-favored-nation (MFN) status to China. These bills were introduced in Congress every year between 1990 (after the Tiananmen Square massacre of June 1989) and 2002 (when China was granted permanent MFN status, following its accession to the WTO). The votes on China MFN status were mostly driven by political considerations and, unlike the votes in our sample, were about maintaining the status quo rather than implementing trade liberalization reforms.

${ }^{7}$ See Conconi, Facchini, and Zanardi (2012) for a theoretical and empirical analysis of the role of fast track authority in international trade negotiations.

${ }^{8}$ As it can be seen from Table A-1, for each decision in the House and Senate less than 435 and 100 votes are reported, respectively. This is because some congressmen may not be present or may decide to abstain. Moreover, a seat in Congress may be vacant at any point in time because of special circumstances (e.g. resignation, death).

${ }^{9}$ Notice that in all but one case the trade reform has been approved, even though the margin of passage varies substantially across bills. In robustness checks, we will distinguish votes by their margin of passage.
} 
such controls (bottom panel). We start with legislators' characteristics.

The main regressors of interest are the indicator variable Senate $_{i}$, which is equal to one for legislators belonging to the upper house, and the indicator variables Senate $_{i t}, G=\{1,2,3\}$, capturing the generation to which senator $i$ belongs in year $t$. As already discussed, one third of the Senate is elected every two years, together with the entire House. We classify senators as belonging to the first (second) generation if they are in the first (middle) two years of their terms. The third generation denotes senators who are in the last two years of their terms and are thus closest to facing re-election.

Party affiliation is known to be a strong predictor of a politician's support for trade liberalization, with Democrats being systematically more protectionist than Republicans for the period under consideration in our study (e.g. Baldwin and Magee 2000; Hiscox 2004; Karol 2007). To assess the role played by a congressman's ideological position, we employ the dummy variable Democrat De $_{i}$ which is equal to one if legislator $i$ belongs to the democratic party, and zero otherwise. ${ }^{10}$

Since trade liberalization bills are usually supported by the administration, legislators' voting behavior may also depend on the congruence (or lack thereof) between their party affiliation and that of the executive. To take this into account, we construct the variable Party as President ${ }_{i t}$, which is equal to one if legislator $i$ belongs to to the same party as the executive in year $t$.

Since age and gender have been shown to be important drivers of individual-level preferences for trade policy (see Mayda and Rodrik 2005), we control for the role of demographic characteristics of a congressman by including the variables Female F $_{i}$ and Age $_{i t}$ in our empirical analysis.

Another set of variables have only been collected for senators, since they are used to verify the robustness of the effects of election proximity. In particular, we have constructed two controls to capture the extent to which legislators are exposed to competition for their seats, in order to assess the role played by re-election incentives in explaining inter-generational differences in senators' voting behavior (see Section 5.4). First, we have used information on the margin of victory recorded by a senator in the last election (i.e. the gap between the share of votes obtained by the winner and the runner-up) to construct the dummy variable $S a f e_{i t}$, which equals one for senators who have last been elected with a large margin of victory. ${ }^{11}$ Second, we have constructed the dummy variable Retiring ${ }_{i t}$, which is equal to 1 for senators who do not seek re-election. ${ }^{12}$

\footnotetext{
${ }^{10}$ As discussed at the end of the section, we have also experimented using alternative measures of ideology (the DW-Nominate scores and the ACU conservative rating index), obtaining very similar results.

${ }^{11}$ We considered seats to be safe if the margin of victory exceeded 60 percent. This threshold corresponds to the average margin of victory in the Senate plus two standard deviations. According to this definition, $4.9 \%$ of observations in our sample refer to safe seats. Example of senators holding safe seats include Charles Timothy Hagel (R, NE), George J. Mitchell (D, ME), Mark Pryor (D, AR), and Charles Patrick Roberts (R, KS). We tried with more demanding thresholds, and our results were even stronger.

${ }^{12}$ Following Overby and Bell (2004), we classify senators as retiring if they voluntarily departed (for personal reasons or to pursue other office), but exclude those who were expelled or defeated in primary or general elections.
} 
A long tradition has emphasized the importance of lobbies' contributions in shaping international trade policy (e.g. Grossman and Helpman 1994; Goldberg and Maggi 1999; Gawande and Bandyopadhyay 2000) and the voting behavior of U.S. congressmen on trade liberalization bills (e.g. Baldwin and Magee 2000). To assess the role of campaign contributions, we have constructed measures of Labor contributions ${ }_{i t}$ and Corporate contributions $s_{i t}$ received by each senator throughout the political cycle. These variables are based on individual-level transactions reported to the Federal Electoral Commission (FEC) since 1979. ${ }^{13}$

In some robustness checks, we also include additional political controls. To account for incumbency effects, we control for whether a senator has been elected more than once (including the dummy variable Incumbent ${ }_{i t}$ ) and for the number of years he or she served in the Senate (captured by the variable Tenure $_{i t}$ ). Since senators are known to be running more often for President than House members (see also Table A-3), we verify whether presidential ambitions influence congressmen's voting behavior by constructing the dummy variable Presidential aspirations ${ }_{i t}$, which captures whether a legislator has taken part in presidential primaries in the years following each vote in the sample. As alternative measures of congressmen's ideological orientation, we try replacing legislators' party affiliation with the ratings provided by the American Conservative Union (ACU) or the DW-Nominate scores (see Poole and Rosenthal 2001). We also investigate the role of membership in the two most powerful Senate committees: the Finance

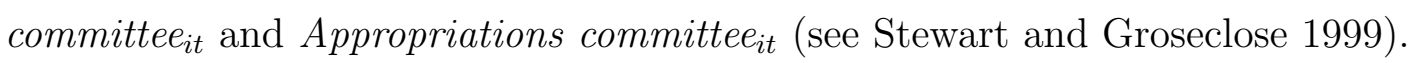

\subsection{Characteristics of constituencies}

In order to capture the trade policy interests of each constituency, we control for the time-varying share of import-competing workers in a given state or congressional district. To do so, we first define an industry (i.e. at 2-digit SIC level or 3-digit NAICS level) as being import-competing (export), if the U.S. as a whole is a net importer (exporter) in that industry in a given year. We then collect information on employment in import-competing and export industries for all constituencies. Such variables can be easily constructed for the Senate, since state-level series are readily available. For the House of Representatives, on the other hand, we encountered two main difficulties. First, congressional district-specific data are not readily available, and must be constructed by aggregating county-level data using the County Business Patterns (CBP), a survey collected by the Bureau of the Census. ${ }^{14}$ Importantly, a county may be split into

\footnotetext{
${ }^{13}$ We have collected information on each transaction between a political action committee (PAC) and an elected congressperson from the FEC website, and aggregated it by political cycle. In this way, we have been able to gather information on the amounts of PAC contributions received by an individual senator throughout his six years in office, rather than just during the last two years of his mandate (the latter information is more readily available).

${ }^{14}$ The CBP report annual data on employment by SIC manufacturing industries up to 1997 and by NAICS manufacturing industries from 1998 onwards, with very little detailed information for agriculture. However, manufacturing industries represent the lion's share of total imports and exports of the United States (i.e. at
} 
different districts, as it is exemplified by Santa Clara County in California (see Figure 1), which encompasses four congressional districts, some of which cover parts of neighboring counties. The second difficulty is that the geographic definition of districts changes over time, following each decennial Census, when districts are re-apportioned following changes in population.

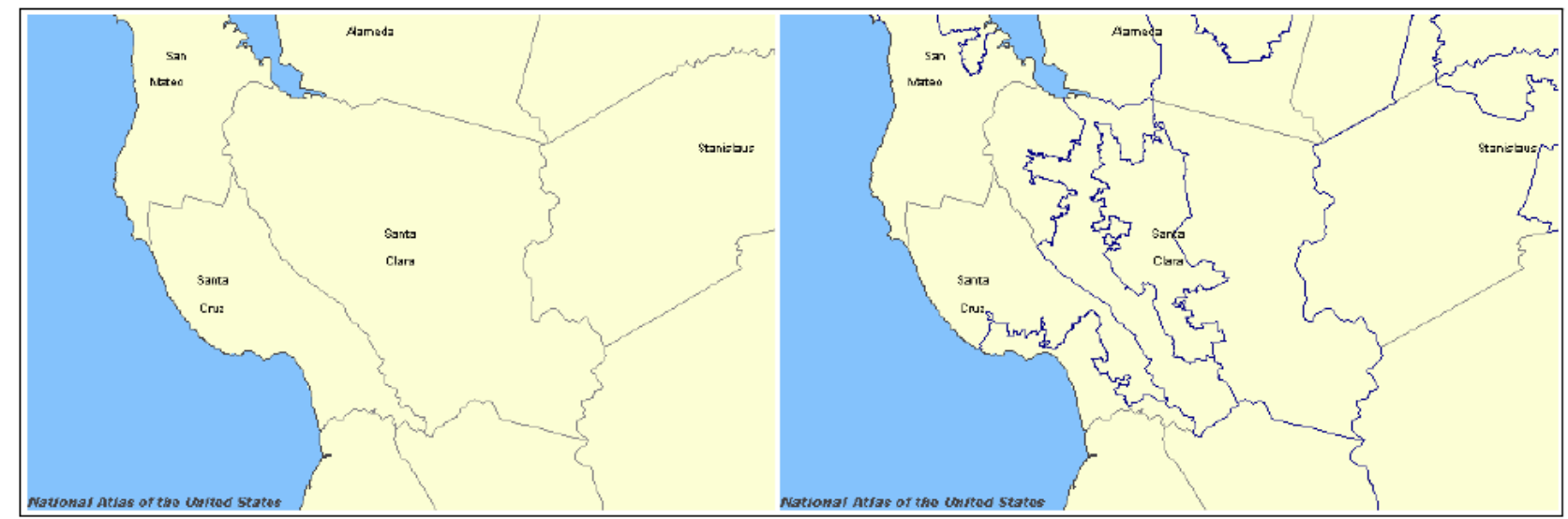

Figure 1: Santa Clara County: Congressional Districts

We have addressed these concerns as follows. To obtain district-level data from county-level information, we first extract yearly county-level data from the CBP and then aggregate them at the district level. For those counties split across more than one district, we follow Baldwin and Magee (2000), among others, imputing employees proportionally to the share of population of a county assigned to that district. To deal with periodical redistricting, we have kept track of changes in the boundaries of the electoral districts that occurred after the Censuses of 1970, 1980, 1990 and 2000. For example, Alaska has always had only one congressional district; between the first vote in 1973 and the last one in 2005, California saw the size of its House delegation increase from 43 to 53 representatives, whereas the number of districts for New York declined from 39 to 29 over the same time period.

Notice that employment data in the CBP are withheld when their disclosure would allow researchers to identify firms. In such cases, a flag gives the interval where the actual data belongs to (e.g. between 0 and 19 employees, between 20 and 99 employees and so on). These flags have been used to input values (i.e. the mid point of each interval) for the missing observations. In order to minimize the problem of undisclosed data, we use CBP employment data at the 2-digit SIC and 3-digit NAICS levels rather than at more disaggregated levels.

Using employment data by congressional district and by state, we compute the number of employees in export and import-competing industries for all constituencies. For each constituency $j$ in year $t$, we then define the variable Export ratio ${ }_{j t}$, which captures dependence on export relative to import-competing jobs. This is defined as the ratio $\frac{X_{j t}}{Y_{j t}}$, where $X_{j t}\left(Y_{j t}\right)$ is the number least 70 percent in each year from 1970 until 2005). Moreover, many agriculture-related activities are classified as manufacturing and are thus included in our dataset (e.g. dairy products, grain mill products, sugar). 
of employees of constituency $j$ in export (import) industries at time $t$. In some specifications, we also use the dummy variable Export ${ }_{j t}$ to capture export-oriented constituencies, which equals 1 when a majority of workers are employed in export industries (i.e. Export ratio Et $_{j}>1$ ).

As an alternative, more long-term measure of the trade interests of a congressman's constituency, we have also constructed a proxy for the relative abundance of skilled labor. In

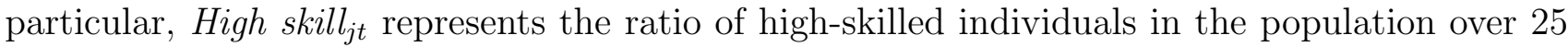
years of age at time $t$ in constituency $j$, where high-skilled individuals are defined as those having earned at least a bachelor degree.

Legislators' voting behavior on trade policy may also be affected by the degree of industry concentration in export and import-competing industries. We thus construct time-varying Herfindahl-Hirschman Indexes for export industries and import-competing industries located in constituency $j$, denoted with HHI exports $s_{j t}$ and HHI imports $s_{j t}$, respectively. Legislators representing larger constituencies may be less responsive to narrowly defined industry interests. We thus control for the size of each constituency, as proxied by Population . $_{\text {. }}$

Table A-3 reports summary statistics for the main variables of interest for the pooled sample of observations for the House and the Senate (used in the first part of our empirical analysis), and for the Senate alone (used in the second part of the analysis). These figures show that trade liberalization bills passed in the Senate by a (statistically significant) larger margin than in the House. The mean of Export ratio ${ }_{j t}$ below 1 suggests constituencies are on average importcompeting. Employment appears to be more concentrated in export industries. The other summary statistics confirm well-known stylized facts about the U.S. Congress (e.g. senators tend to be older than House members and to run more often for President).

\section{Inter-cameral differences in voting behavior}

In this section, we start by examining the voting behavior of all congressmen, to verify whether House members are more protectionist than Senate members, as previously argued by Karol (2007). We then contrast House members with different generations of senators to establish whether inter-cameral differences are driven by term length.

\subsection{House vs Senate}

We first compare the behavior of Senate and House members. The dependent variable in our analysis, $V$ ote $e_{i j t}$, is dichotomous and equals one if legislator $i$ representing constituency $j$ votes in favor of a trade liberalization bill in year $t$, and zero otherwise. We estimate the following probabilistic model:

$$
\operatorname{Prob}\left(\text { Vote }_{i j t}=1\right)=\Phi\left(\beta_{0}+\beta_{1} \text { Senate }^{j}+\beta_{2} \mathbf{X}_{i t}+\beta_{3} \mathbf{Z}_{j t}+\mu_{j}+\delta_{t}+\epsilon_{i j t}\right)
$$


where $\Phi(\cdot)$ is the cumulative normal distribution (i.e. probit model) and House members are the omitted category. The main variable of interest is the Senate dummy. The matrix $\mathbf{X}_{i t}$ includes additional controls for legislators (e.g. party affiliation, gender, age), while $\mathbf{Z}_{j t}$ is a matrix of contituency-specific characteristics (e.g. population, export ratio). We include two sets of fixed effects: $\mu_{j}$ are state dummies, capturing time-invariant state characteristics that may affect senators' voting behavior; $\delta_{t}$ are year dummies, which enables us to account for year-specific determinants of congressmen's votes on trade reforms.

We cluster standard errors by state, to allow for correlation in the trade policy stance of politicians who represent the same state. ${ }^{15}$ In order to facilitate the interpretation of the estimated coefficients, in the tables we report marginal effects (calculated at the mean of each regressor).

Table 1: Trade Liberalization votes: House vs Senate

\begin{tabular}{|c|c|c|c|c|c|c|}
\hline & $(1)$ & $(2)$ & (3) & (4) & $(5)$ & $(6)$ \\
\hline Senate $_{i t}$ & $\begin{array}{c}0.064^{* *} \\
(0.025)\end{array}$ & $\begin{array}{c}0.110^{* * *} \\
(0.024)\end{array}$ & $\begin{array}{c}0.083^{* * *} \\
(0.026)\end{array}$ & $\begin{array}{c}0.087^{* * *} \\
(0.033)\end{array}$ & $\begin{array}{c}0.087^{* * *} \\
(0.033)\end{array}$ & $\begin{array}{c}0.087^{* * *} \\
(0.032)\end{array}$ \\
\hline Democrat $_{i}$ & & & & $\begin{array}{c}-0.302^{* * *} \\
(0.029)\end{array}$ & $\begin{array}{c}-0.303^{* * *} \\
(0.028)\end{array}$ & $\begin{array}{c}-0.291^{* * *} \\
(0.028)\end{array}$ \\
\hline Party as President $i t$ & & & & $\begin{array}{c}0.080^{* * *} \\
(0.016)\end{array}$ & $\begin{array}{c}0.080^{* * *} \\
(0.016)\end{array}$ & $\begin{array}{c}0.084^{* * *} \\
(0.017)\end{array}$ \\
\hline Female $_{i}$ & & & & $\begin{array}{l}-0.037 \\
(0.029)\end{array}$ & $\begin{array}{l}-0.038 \\
(0.028)\end{array}$ & $\begin{array}{c}-0.056^{* *} \\
(0.028)\end{array}$ \\
\hline $\operatorname{Age}_{i t}$ & & & & $\begin{array}{c}-0.002^{* *} \\
(0.001)\end{array}$ & $\begin{array}{c}-0.002^{* *} \\
(0.001)\end{array}$ & $\begin{array}{c}-0.002^{* * *} \\
(0.001)\end{array}$ \\
\hline Population $_{j t}$ & & & & $\begin{array}{c}0.003 \\
(0.004)\end{array}$ & $\begin{array}{c}0.003 \\
(0.003)\end{array}$ & $\begin{array}{c}0.003 \\
(0.003)\end{array}$ \\
\hline Export Ratio $_{j t}$ & & & & $\begin{array}{l}0.044^{*} \\
(0.027)\end{array}$ & $\begin{array}{c}0.060^{* *} \\
(0.030)\end{array}$ & \\
\hline HHI Exports $_{j t}$ & & & & & $\begin{array}{l}-0.105 \\
(0.089)\end{array}$ & \\
\hline HHI Imports $j t$ & & & & & $\begin{array}{c}0.109 \\
(0.123)\end{array}$ & \\
\hline $\operatorname{High~Skill~}_{j i}$ & & & & & & $\begin{array}{c}0.777^{* * *} \\
(0.158)\end{array}$ \\
\hline Year effects & included & & included & included & included & included \\
\hline State effects & & included & included & included & included & included \\
\hline Observations & 7,664 & 7,664 & 7,664 & 7,664 & 7,664 & 7,661 \\
\hline Pseudo $R^{2}$ & 0.10 & 0.06 & 0.16 & 0.27 & 0.27 & 0.28 \\
\hline Log likelihood & $-4,296.29$ & $-4,465.14$ & $-3,988.51$ & $-3,494.29$ & $-3,491.97$ & $-3,452.41$ \\
\hline Predicted probability & 0.72 & 0.70 & 0.73 & 0.75 & 0.75 & 0.75 \\
\hline
\end{tabular}

\footnotetext{
${ }^{15}$ The results are unaffected if we cluster standard errors by state-decade, allowing for the geographical correlation within each state to change over time.
} 
Our first set of results is presented in Table $1 .{ }^{16}$ In the first three columns, we report the findings from a series of parsimonious specifications, where the only explanatory variables are the Senate dummy and a set of year or state fixed effects, or both. We find that senators are more likely to support trade liberalization bills. ${ }^{17}$ The estimates of year and state fixed effects (not reported) are jointly significant. ${ }^{18}$ In the remainder of the table, we investigate the role played by additional drivers of trade liberalization votes which have been identified by the existing literature.

In column (4), we control for a congressman's party affiliation and whether it is the same as that of the executive. We also account for demographic characteristics of the legislators, as well as for the size and the trade interests of a constituency. Inter-cameral differences in congressmen's voting behavior on trade reforms are sizable: Senate membership increases the probability of supporting trade liberalization by 11.6 percentage points. ${ }^{19}$ Concerning the other legislators' controls, we find that support for trade reforms is significantly lower for members of the Democratic party. Legislators who belong to the same party as the executive are more likely to vote in favor of trade liberalization bills, while older legislators tend to be more protectionist. In terms of state characteristics, the coefficient Export ratio is positive and significant, suggesting that the larger is the share of export workers in a constituency, the more likely its representative is to favor a reduction in trade barriers. In line with the results of Karol (2007), congressmen's trade votes are unrelated to constituency size, as proxied by Population. ${ }^{20}$

The estimates reported in column (5) show that inter-cameral differences are robust to the inclusion of concentration measures for export and import-competing industries. Notice that this leads to a more precisely estimated and more significant coefficient for Export ratio.

Finally, in column (6) we replace our trade orientation measure based on sectoral employment with one based on factor endowments. We find that congressmen representing more highly skilled districts are more likely to support trade liberalization measures, a result consistent with a Heckscher-Ohlin model in which U.S. imports are relatively unskilled-labor intensive. In all specifications, the estimate for the Senate dummy is positive and significant, confirming the importance of inter-cameral differences.

\footnotetext{
${ }^{16}$ For simplicity, when discussing the regression results, we drop all $i, j$ and $t$ subscripts.

${ }^{17}$ In the simplest possible specification with only the Senate dummy, its coefficient is also positive and significant at the 1 percent level.

${ }^{18}$ The estimates for the year dummies indicate that during the past four decades there has been an erosion of support for trade liberalization.

${ }^{19}$ This result is obtained by diving the marginal effect of the dummy variable Senate in column (4) of Table 1 (0.087) by the average predicted probability of a vote in favor of trade liberalization reported at the bottom of the table $(0.75)$.

${ }^{20}$ Thus constituency size does not affect legislators' support for broad trade liberalization reforms. This is somewhat in contrast with results obtained by Hauk (2011) for Senate votes on agricultural tariffs during the late 19 th and early 20 th centuries. He finds that a senator is more likely to vote in favor of a tariff on an industry that is disproportionately concentrated in his state relative to that state's population.
} 


\subsection{House vs different generations of senators}

Next, we exploit the staggered nature of senators' mandates. This specific institutional feature of the U.S. Congress implies that, at any point in time, one third of the senators have the same "political horizon" as House members (i.e. they face elections in less than two years).

Table 2: Trade Liberalization votes: House vs generations of senators

\begin{tabular}{|c|c|c|c|c|c|c|}
\hline & $(1)$ & $(2)$ & $(3)$ & $(4)$ & $(5)$ & $(6)$ \\
\hline \multirow[t]{2}{*}{ Senate $3_{i t}$} & 0.015 & $0.063^{* *}$ & 0.032 & 0.039 & 0.039 & 0.040 \\
\hline & $(0.032)$ & $(0.028)$ & $(0.031)$ & $(0.037)$ & $(0.038)$ & $(0.037)$ \\
\hline \multirow[t]{2}{*}{ Senate $2_{i t}$} & $0.079^{* * *}$ & $0.133^{* * *}$ & $0.104^{* * *}$ & $0.109^{* * *}$ & $0.109^{* * *}$ & $0.108^{* * *}$ \\
\hline & $(0.028)$ & $(0.024)$ & $(0.026)$ & $(0.031)$ & $(0.031)$ & $(0.031)$ \\
\hline \multirow[t]{2}{*}{ Senate $_{i t}$} & $0.095^{* * *}$ & $0.124^{* * *}$ & $0.107^{* * *}$ & $0.103^{* * *}$ & $0.102^{* * *}$ & $0.103^{* * *}$ \\
\hline & $(0.027)$ & $(0.029)$ & $(0.028)$ & $(0.034)$ & $(0.034)$ & $(0.034)$ \\
\hline \multirow[t]{2}{*}{ Democrat $_{i}$} & & & & $-0.302^{* * *}$ & $-0.302^{* * *}$ & $-0.290 * * *$ \\
\hline & & & & $(0.029)$ & $(0.029)$ & (0.029) \\
\hline \multirow[t]{2}{*}{ Party as President $_{i t}$} & & & & $0.081^{* * *}$ & $0.080^{* * *}$ & $0.085^{* * *}$ \\
\hline & & & & $(0.016)$ & $(0.016)$ & $(0.016)$ \\
\hline \multirow[t]{2}{*}{ Female $_{i}$} & & & & -0.038 & -0.039 & $-0.057^{* *}$ \\
\hline & & & & $(0.029)$ & $(0.028)$ & $(0.028)$ \\
\hline \multirow[t]{2}{*}{$\operatorname{Age}_{i t}$} & & & & $-0.002^{* *}$ & $-0.002^{* *}$ & $-0.002^{* * *}$ \\
\hline & & & & $(0.001)$ & $(0.001)$ & $(0.001)$ \\
\hline \multirow[t]{2}{*}{ Population $_{j t}$} & & & & 0.004 & 0.004 & 0.004 \\
\hline & & & & $(0.004)$ & $(0.004)$ & $(0.003)$ \\
\hline \multirow[t]{2}{*}{ 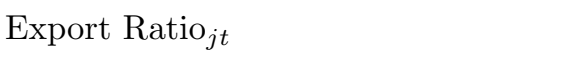 } & & & & $0.045^{*}$ & $0.062^{* *}$ & \\
\hline & & & & $(0.027)$ & $(0.030)$ & \\
\hline \multirow[t]{2}{*}{ HHI Exports $_{j t}$} & & & & & -0.106 & \\
\hline & & & & & $(0.089)$ & \\
\hline \multirow[t]{2}{*}{ HHI Imports $_{j t}$} & & & & & 0.109 & \\
\hline & & & & & $(0.123)$ & \\
\hline High Skill $_{j t}$ & & & & & & $0.777^{* * *}$ \\
\hline Year effects & included & & included & included & included & $\begin{array}{l}\text { (0.158) } \\
\text { included }\end{array}$ \\
\hline State effects & & included & included & included & included & included \\
\hline Test Senate $3_{i t}=$ Senate $_{i t}(\mathrm{p}$-value $)$ & 0.018 & 0.005 & 0.006 & 0.007 & 0.007 & 0.008 \\
\hline Test Senate $3_{i t}=$ Senate $_{i t}(\mathrm{p}$-value $)$ & 0.001 & 0.018 & 0.003 & 0.017 & 0.017 & 0.016 \\
\hline Test Senate $2_{i t}=$ Senate $_{i t}(\mathrm{p}$-value $)$ & 0.536 & 0.710 & 0.888 & 0.821 & 0.803 & 0.859 \\
\hline Observations & 7,664 & 7,664 & 7,664 & 7,664 & 7,664 & 7,661 \\
\hline Pseudo $R^{2}$ & 0.10 & 0.06 & 0.16 & 0.27 & 0.27 & 0.28 \\
\hline Log likelihood & $-4,292.12$ & $-4,461.44$ & $-3,984.28$ & $-3,490.49$ & $-3,488.15$ & $-3,448.68$ \\
\hline Predicted probability & 0.72 & 0.70 & 0.73 & 0.75 & 0.75 & 0.76 \\
\hline
\end{tabular}

The table reports marginal effects of probit regressions. The dependent variable, Vote $_{i j t}$, equals 1 if legislator $i$ representing constituency $j$ votes in favor of trade liberalization in year $t, 0$ otherwise. Standard errors clustered at state level in parenthesis; $* * *$ denotes significance at $1 \%$ level; $* * 5 \%$ level; ${ }^{*} 10 \%$ level.

This gives rise to a quasi experimental setting: since electoral calendars are exogenously assigned to each Senate seat, we can compare the voting of legislators with different remaining time in office. We estimate the following probit model:

$\operatorname{Prob}\left(\right.$ Vote $\left._{i j t}=1\right)=\Phi\left(\gamma_{0}+\gamma_{1}\right.$ Senate $_{i t}+\gamma_{2}$ Senate $_{i t}+\gamma_{3}$ Senate $\left.3_{i t}+\gamma_{4} \mathbf{X}_{i t}+\gamma_{5} \mathbf{Z}_{j t}+\mu_{j}+\delta_{t}+\epsilon_{i j t}\right)$

where House members are the omitted category. The main regressors of interest are the dummy variables for the three generations of senators. In particular, the coefficient of the variable 
Senate3 captures the stance of senators who belong to the third generation and thus face reelection within two years, at the same time as all House members.

In Table 2 we replicate the same specifications reported in Table 1, distinguishing between different generations of senators. Notice that, in all specifications in which we control for time effects, the coefficient for senators belonging to the third generation is never significant, while the estimates for the other two generations are always positive and significant at the $1 \%$ level. ${ }^{21}$ Depending on the specification, senators from the first generation are between 13.2 and 17.7 percent more likely to support trade liberalization bills (over the average predicted probability) than members of the House. ${ }^{22}$ The $\chi^{2}$ tests at the bottom of the table indicate that their behavior is not statistically different from that of the second generation, while third-generation senators are significantly more protectionist than the others. As for the effect of the additional controls, their impact is the same as in Table 1.

\subsection{Additional robustness checks}

To assess the robustness of our results on inter-cameral comparisons, we have performed a series of additional estimations, focusing on economic and political drivers of congressmen's voting behavior and restricting the analysis to different subsamples of bills. The results of these estimations are available upon request.

First, we have introduced additional controls for legislators' constituencies (i.e. real GDP per capita, unemployment rate, and the share of the population over 65). ${ }^{23}$ In line with previous studies, we find a negative and significant effect of unemployment on the support for trade liberalization. Including these variables does not alter our results on the comparison between House members and different generations of senators.

The trade variable used in our benchmark analysis is based on whether the United States is a net importer/exporter in a given industry relative to the rest of the world. It may be argued that this is an imprecise measure when it comes to the ratification of preferential trade agreements (PTAs), because of the idiosyncrasies of U.S. trade patterns. ${ }^{24}$ For these votes, we have thus constructed a different version of the Export ratio variable, based on the net trade position of the United States vis-à-vis PTA partners. The qualitative results of our analysis are unaffected when using this alternative measure of constituencies' trade interests.

We have also included additional political controls for the legislators. In particular, we have accounted for whether they are serving their first mandate, and for their tenure in office. The

\footnotetext{
${ }^{21}$ The coefficient $\gamma_{3}$ is insignificant even in the simplest specification including only the generations dummies.

${ }^{22}$ These results are obtained by diving the marginal effects for Senate 1 in Table 2 by the average predicted probability of a vote in favor of trade liberalization reported at the bottom of the table.

${ }^{23}$ These variables are not included in the benchmark analysis of Tables 1 and 2, since they are only available at the state level.

${ }^{24}$ For example, in recent years, the U.S. is an overall net importer of "Textile Product Mills", but it is a net exporter of these goods to Australia, Chile, Singapore, with which it has signed a PTA.
} 
variables Incumbent and Tenure do not have a significant effect on legislators' voting behavior on trade reforms and their inclusion does not alter our results on inter-cameral differences. The same is true if we replace party affiliation with alternative measures of congressmen's ideological orientation (ACU ratings and the DW-Nominate scores).

We have also carried out our analysis on different subsamples of votes, to investigate whether our findings apply to different kinds of trade liberalization reforms. First, we have excluded bills on the conferral or extension of fast track authority, since their trade effects are less clear cut (see Conconi, Facchini, and Zanardi 2012). Second, we have examined separately the ratification of multilateral and regional trade agreements, which can have different welfare implications. Finally, we have restricted our analysis to the most important bills in our sample, i.e. the ratification of the Tokyo and Uruguay Rounds of GATT-WTO negotiations and of the most important regional trade agreements (CUSFTA and NAFTA). Our results on inter-cameral and inter-generational differences in congressmen's voting behavior continue to hold.

\section{Different generations of senators}

We now move to the core of our analysis, in which we examine the role of election proximity on legislators' voting behavior. To do so, we focus on votes cast in the U.S. Senate alone, exploiting its staggered structure and the fact that many of its members have voted on several trade bills during their careers.

We follow two complementary strategies to identify the effect of election proximity. First, we compare the voting behavior of senators who belong to different generations. We estimate the following probit model, in which the first generation is taken as the omitted category:

$$
\operatorname{Prob}\left(\text { Vote }_{i j t}=1\right)=\Phi\left(\delta_{0}+\delta_{1} \text { Senate }_{i t}+\delta_{2} \text { Senate }_{i t}+\delta_{3} \mathbf{X}_{i t}+\delta_{4} \mathbf{Z}_{j t}+\mu_{j}+\delta_{t}+\epsilon_{i j t}\right) .
$$

Second, since our sample spans four decades, we can observe the votes that the same senator has cast on different trade bills. We can thus exploit the time variation in the voting behavior of individual senators. To this end, we include senators' fixed effects and estimate the following conditional logit model: ${ }^{25}$

$$
\operatorname{Prob}\left(\text { Vote }_{i j t}=1\right)=\Omega\left(\lambda_{0}+\lambda_{1} \text { Senate }_{i t}+\lambda_{2} \text { Senate }_{i t}+\lambda_{3} \mathbf{X}_{i t}+\lambda_{4} \mathbf{Z}_{j t}+\omega_{i}+\delta_{t}+\epsilon_{i j t}\right) .
$$

Notice that this estimator only retains observations for senators who voted on more than one bill (and not always in favor or against protection), which greatly reduces the sample. Moreover,

\footnotetext{
${ }^{25}$ Since our dependent variable is defined at the senator level, including senator fixed effects in a probit model would raise concerns about the incidental parameters problem. By contrast, year and state fixed effects can be used in our probit regressions, since they refer to a more aggregate dimension than the unit of our analysis.
} 
since the congressmen's fixed effects are not estimated, marginal effects cannot be computed when estimating a conditional logit model, which limits the comparison with our previous results. In order to overcome these issues, we will also report the results of a linear probability model.

\subsection{Comparison across senators}

The results reported in Table 3 are based on the analysis of the voting behavior of senators who belong to different generations. Notice that the marginal effect for the variable Senate3 is always negative and statistically significant at the 1 percent level. Thus, senators who are in the last two years of their terms are less likely to support trade liberalization reforms than the omitted category (senators in the first two years of their terms).

In terms of magnitude, the estimates of the benchmark specification in column (4) suggest that third-generation senators are around 10 percentage point less likely to support trade liberalization. ${ }^{26}$ This can also be seen in Figure 2, where we plot predicted probabilities for senators belonging to different generations. ${ }^{27}$

Figure 2: Predicted probabilities, different generations of senators

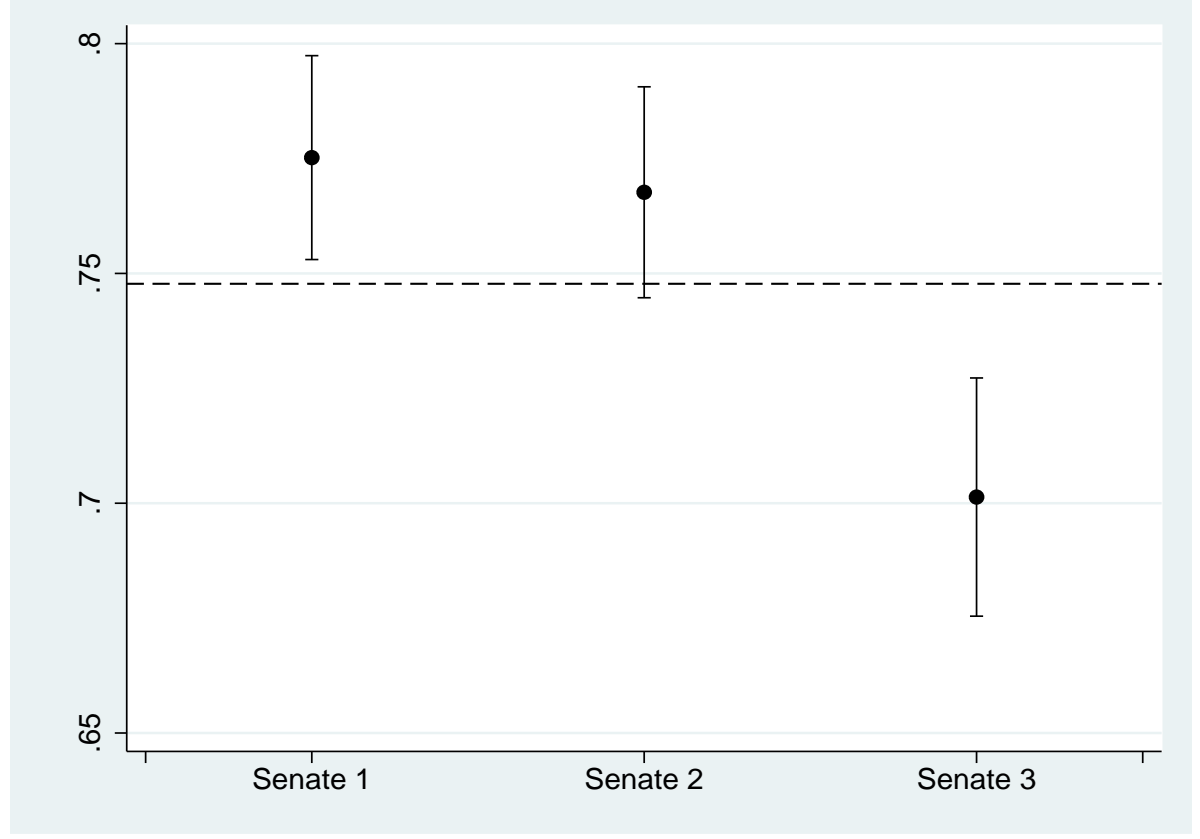

\footnotetext{
${ }^{26}$ This result is obtained by dividing the marginal effect for Senate3 $(0.081)$ by the average predicted probability reported at the bottom of the table $(0.84)$.

${ }^{27}$ The dotted line in Figure 2 depicts the average predicted probability that senators vote in favor of trade reforms (based on column 4 of Table 3); the dots are the predicted probabilities of different generations of senators, while the bars represent their $95 \%$ confidence interval.
} 
Table 3: The protectionist effect of election proximity, comparing across senators

\begin{tabular}{|c|c|c|c|c|c|c|c|}
\hline & $(1)$ & $(2)$ & $(3)$ & $(4)$ & $(5)$ & $(6)$ & $(7)$ \\
\hline Senate $3_{i t}$ & $\begin{array}{c}-0.077^{* * *} \\
(0.026)\end{array}$ & $\begin{array}{c}-0.075^{* * *} \\
(0.028)\end{array}$ & $\begin{array}{c}-0.090^{* * *} \\
(0.026)\end{array}$ & $\begin{array}{c}-0.081^{* * *} \\
(0.028)\end{array}$ & $\begin{array}{c}-0.082^{* * *} \\
(0.027)\end{array}$ & $\begin{array}{c}-0.079^{* * *} \\
(0.028)\end{array}$ & $\begin{array}{c}-0.103^{* * *} \\
(0.032)\end{array}$ \\
\hline Senate $2_{i t}$ & $\begin{array}{l}-0.015 \\
(0.027)\end{array}$ & $\begin{array}{c}0.000 \\
(0.030)\end{array}$ & $\begin{array}{l}-0.017 \\
(0.029)\end{array}$ & $\begin{array}{l}-0.004 \\
(0.028)\end{array}$ & $\begin{array}{l}-0.005 \\
(0.028)\end{array}$ & $\begin{array}{l}-0.008 \\
(0.028)\end{array}$ & $\begin{array}{c}-0.023 \\
(0.028)\end{array}$ \\
\hline Democrat $_{i}$ & & & & $\begin{array}{c}-0.118^{* * *} \\
(0.040)\end{array}$ & $\begin{array}{c}-0.115^{* * *} \\
(0.041)\end{array}$ & $\begin{array}{c}-0.123^{* * *} \\
(0.039)\end{array}$ & $\begin{array}{l}-0.062 \\
(0.043)\end{array}$ \\
\hline Party as President $i t$ & & & & $\begin{array}{c}0.066^{* * *} \\
(0.025)\end{array}$ & $\begin{array}{c}0.065^{* * *} \\
(0.024)\end{array}$ & $\begin{array}{c}0.067 * * * \\
(0.025)\end{array}$ & $\begin{array}{c}0.055^{* *} \\
(0.025)\end{array}$ \\
\hline Female $_{i}$ & & & & $\begin{array}{l}-0.044 \\
(0.058)\end{array}$ & $\begin{array}{c}-0.049 \\
(0.061)\end{array}$ & $\begin{array}{l}-0.040 \\
(0.059)\end{array}$ & $\begin{array}{l}-0.019 \\
(0.052)\end{array}$ \\
\hline $\operatorname{Age}_{i t}$ & & & & $\begin{array}{c}-0.005^{* * *} \\
(0.002)\end{array}$ & $\begin{array}{c}-0.005^{* * *} \\
(0.002)\end{array}$ & $\begin{array}{c}-0.005^{* * *} \\
(0.002)\end{array}$ & $\begin{array}{c}-0.005^{* * *} \\
(0.002)\end{array}$ \\
\hline Population $_{j t}$ & & & & $\begin{array}{c}0.007 \\
(0.015)\end{array}$ & $\begin{array}{c}0.007 \\
(0.015)\end{array}$ & $\begin{array}{c}0.008 \\
(0.015)\end{array}$ & $\begin{array}{c}0.012 \\
(0.014)\end{array}$ \\
\hline Export $_{\text {Ratio }_{j t}}$ & & & & $\begin{array}{c}0.101^{*} \\
(0.055)\end{array}$ & $\begin{array}{c}0.137^{* *} \\
(0.059)\end{array}$ & & $\begin{array}{l}0.109^{*} \\
(0.057)\end{array}$ \\
\hline HHI Exports $_{j t}$ & & & & & $\begin{array}{l}-0.058 \\
(0.205)\end{array}$ & & \\
\hline HHI Imports ${ }_{j t}$ & & & & & $\begin{array}{c}0.435 \\
(0.495)\end{array}$ & & \\
\hline High Skill $j t$ & & & & & & $\begin{array}{c}-0.604 \\
(1.636)\end{array}$ & \\
\hline Labor contributions $_{i t}$ & & & & & & & $\begin{array}{c}-0.068^{* * *} \\
(0.018)\end{array}$ \\
\hline Corporate contributions $_{i t}$ & & & & & & & $\begin{array}{c}0.024^{* * *} \\
(0.006)\end{array}$ \\
\hline Year effects & included & & included & included & included & included & included \\
\hline State effects & & included & included & included & included & included & included \\
\hline Test Senate $3_{i t}=$ Senate $2_{i t}(\mathrm{p}$-value $)$ & 0.015 & 0.009 & 0.009 & 0.006 & 0.006 & 0.010 & 0.011 \\
\hline Observations & 1,331 & 1,254 & 1,254 & 1,254 & 1,254 & 1,254 & 1,254 \\
\hline Pseudo $R^{2}$ & 0.09 & 0.17 & 0.28 & 0.32 & 0.32 & 0.31 & 0.33 \\
\hline Log likelihood & -661.04 & -583.65 & -508.83 & -482.90 & -481.85 & -485.85 & -472.17 \\
\hline Predicted probability & 0.79 & 0.79 & 0.82 & 0.84 & 0.83 & 0.83 & 0.84 \\
\hline
\end{tabular}

The table reports marginal effects of probit regressions. The dependent variable, Vote ijt $_{\text {, equals } 1 \text { if senator } i \text { representing }}$ constituency $j$ votes in favor of trade liberalization in year $t, 0$ otherwise. Standard errors clustered at state level in parenthesis; $* * *$ denotes significance at $1 \%$ level; $* * 5 \%$ level; ${ }^{*} 10 \%$ level. 
The estimates for the other regressors are in line with the results obtained in the previous section. However, party affiliation has a much smaller effect, indicating that the difference between Democrats and Republicans is larger in the House than in the Senate. The estimated coefficient for the dummy Party as President is also smaller than in Tables 1-2. On the contrary, age seems to have a bigger impact on senators than on House representatives, whereas the district's skill composition does no longer have a significant effect on support for trade liberalization. ${ }^{28}$ Overall, the qualitative conclusions that we reached when comparing senators are the same as those identified in Section 4: there is clear evidence of a protectionist effect as senators approach the end of their mandate.

Much of the existing literature on the political economy of trade policy has emphasized the role of lobbying. In column (7) we investigate whether our results on inter-generational differences in senators' voting behavior are robust to controlling for the influence of organized pressure groups. In particular, we supplement our benchmark specification (reported in column 4) by accounting separately for the amount of corporate and labor contributions received by a given senator during each congressional cycle, i.e. when belonging to different generations. In line with what found in previous studies (e.g. Baldwin and Magee 2000), we find that labor (corporate) contributions have a significant negative (positive) impact on legislators' support for trade liberalization bills. Crucially, however, the inclusion of these additional regressors does not affect our main result: the coefficient of the Senate3 dummy remains negative and statistically significant at the 1 percent level. This suggests that the protectionist effect of election proximity is not driven by cycles in campaign contributions.

\subsection{Comparison within senators}

We now turn to the analysis of the impact of election proximity on the voting behavior of individual senators. This alternative strategy allows us to account for time-invariant unobservable characteristics of legislators that can affect their stance on trade policy.

Table 4 reports the results of estimations that include fixed effects for individual legislators, using both a conditional logit model (columns 1-4) and a linear probability model (columns 5-8). We consider the same specifications as in Table 3, but exclude the Female and Democrat controls, as well as the state fixed effects, since they show little or no variation at the individual level. We also exclude Age, as it is collinear with year fixed effects in these specifications. Notice also that, in the conditional logit estimations, only the observations for senators who voted more than once and changed their behavior across trade liberalization bills are retained. As a result, in these regressions the sample size is reduced to 754 observations. ${ }^{29}$

\footnotetext{
${ }^{28}$ This latter result is not surprising, since in Table 3 we only exploit state-level variation in this measure, constructed from the decennial U.S. Census.

${ }^{29}$ The results reported in Table 4 are based on regressions in which we cluster standard errors at the state level. The significance of our results is unaffected if we cluster standard errors at the senator level.
} 
Table 4: The protectionist effect of election proximity, comparing within senators

\begin{tabular}{|c|c|c|c|c|c|c|c|c|}
\hline & $(1)$ & $(2)$ & $(3)$ & $(4)$ & $(5)$ & $(6)$ & $(7)$ & $(8)$ \\
\hline Senate $3_{i t}$ & $\begin{array}{c}-0.885^{* * *} \\
(0.182)\end{array}$ & $\begin{array}{c}-0.875^{* * *} \\
(0.182)\end{array}$ & $\begin{array}{c}-0.882^{* * *} \\
(0.184)\end{array}$ & $\begin{array}{c}-0.869^{* * *} \\
(0.224)\end{array}$ & $\begin{array}{c}-0.094^{* * *} \\
(0.025)\end{array}$ & $\begin{array}{c}-0.093^{* * *} \\
(0.025)\end{array}$ & $\begin{array}{c}-0.092^{* * *} \\
(0.025)\end{array}$ & $\begin{array}{c}-0.093^{* * *} \\
(0.028)\end{array}$ \\
\hline Senate $2_{i t}$ & $\begin{array}{l}-0.288 \\
(0.192)\end{array}$ & $\begin{array}{l}-0.255 \\
(0.199)\end{array}$ & $\begin{array}{c}-0.315^{*} \\
(0.188)\end{array}$ & $\begin{array}{c}-0.321^{*} \\
(0.191)\end{array}$ & $\begin{array}{l}-0.030 \\
(0.026)\end{array}$ & $\begin{array}{l}-0.029 \\
(0.025)\end{array}$ & $\begin{array}{l}-0.033 \\
(0.026)\end{array}$ & $\begin{array}{l}-0.032 \\
(0.025)\end{array}$ \\
\hline Party as President $i t$ & $\begin{array}{c}0.638^{* * *} \\
(0.244)\end{array}$ & $\begin{array}{c}0.664^{* * *} \\
(0.248)\end{array}$ & $\begin{array}{c}0.642^{* * *} \\
(0.238)\end{array}$ & $\begin{array}{c}0.630^{* * *} \\
(0.243)\end{array}$ & $\begin{array}{c}0.056^{* *} \\
(0.022)\end{array}$ & $\begin{array}{c}0.053^{* *} \\
(0.022)\end{array}$ & $\begin{array}{c}0.057^{* *} \\
(0.022)\end{array}$ & $\begin{array}{c}0.053^{* *} \\
(0.022)\end{array}$ \\
\hline Population $_{j t}$ & $\begin{array}{c}0.352^{* *} \\
(0.144)\end{array}$ & $\begin{array}{c}0.366^{* *} \\
(0.149)\end{array}$ & $\begin{array}{c}0.379^{* * *} \\
(0.144)\end{array}$ & $\begin{array}{c}0.351^{* *} \\
(0.151)\end{array}$ & $\begin{array}{c}0.040^{* *} \\
(0.018)\end{array}$ & $\begin{array}{c}0.039^{* *} \\
(0.018)\end{array}$ & $\begin{array}{c}0.039^{* *} \\
(0.018)\end{array}$ & $\begin{array}{c}0.041^{* *} \\
(0.018)\end{array}$ \\
\hline Export Ratio $_{j t}$ & $\begin{array}{c}0.699 \\
(0.491)\end{array}$ & $\begin{array}{c}1.450^{* * *} \\
(0.518)\end{array}$ & & $\begin{array}{c}0.719 \\
(0.512)\end{array}$ & $\begin{array}{c}0.082^{*} \\
(0.047)\end{array}$ & $\begin{array}{c}0.157^{* * *} \\
(0.058)\end{array}$ & & $\begin{array}{c}0.081^{*} \\
(0.048)\end{array}$ \\
\hline $\mathrm{HHI}_{\text {Exports }}{ }_{j t}$ & & $\begin{array}{l}-1.203 \\
(1.449)\end{array}$ & & & & $\begin{array}{c}-0.061 \\
(0.191)\end{array}$ & & \\
\hline HHI Imports $j t$ & & $\begin{array}{c}6.611 \\
(5.138)\end{array}$ & & & & $\begin{array}{c}0.990 \\
(0.600)\end{array}$ & & \\
\hline High Skill $_{j t}$ & & & $\begin{array}{c}4.304 \\
(16.305)\end{array}$ & & & & $\begin{array}{c}0.256 \\
(2.337)\end{array}$ & \\
\hline Labor contributions $_{i t}$ & & & & $\begin{array}{l}-0.184 \\
(0.156)\end{array}$ & & & & $\begin{array}{l}-0.020 \\
(0.019)\end{array}$ \\
\hline Corporate contributions $_{i t}$ & & & & $\begin{array}{c}0.045 \\
(0.060)\end{array}$ & & & & $\begin{array}{c}0.005 \\
(0.006)\end{array}$ \\
\hline Year and senator effects & included & included & included & included & included & included & included & included \\
\hline Test Senate $3_{i t}=$ Senate $2_{i t}(\mathrm{p}$-value $)$ & 0.006 & 0.006 & 0.010 & 0.034 & 0.038 & 0.043 & 0.047 & 0.064 \\
\hline Observations & 754 & 754 & 754 & 754 & 1,331 & 1,331 & 1,331 & 1,331 \\
\hline Pseudo $R^{2}$ & 0.23 & 0.24 & 0.23 & 0.23 & & & & \\
\hline Log likelihood & -246.15 & -242.73 & -247.73 & -245.48 & -333.21 & -328.26 & -335.85 & -332.02 \\
\hline
\end{tabular}

The table reports coefficient estimates of conditional logit (linear probability) models for all regressors in the first (last) four columns.

The dependent variable, Vote $e_{i j t}$, equals 1 if legislator $i$ representing constituency $j$ votes in favor of trade liberalization in year $t, 0$ otherwise. Standard errors clustered at the state level in parenthesis; *** denotes significance at $1 \%$ level; $* * 5 \%$ level; * $10 \%$ level. 
As it can be seen from all the specifications included in the table, a senator in the last two years of his mandate is systematically less likely to support trade liberalization than the same individual in the first four years of his mandate. In fact, various senators never supported trade liberalization bill in the last two years before re-election, but did vote in favor at least once earlier in their terms. ${ }^{30}$

The conditional logit estimator does not allow to compute marginal effects, since the congressmen's fixed effects are not estimated. To get a sense of the magnitude of the effects, we can look at the estimates of the linear probability model in columns (5)-(8) of Table 4. The results for the generations of senators are very similar to those reported in Table 3, confirming once again that legislators become more protectionist as they approach their re-election date. The estimates for the other regressors are also in line with our previous findings. The only notable difference is that labor and corporate PAC contributions no longer have a significant impact on senators' voting behavior.

The results of Table 4 show that individual senators "flip flop" on trade policy, supporting trade liberalization reforms earlier in their terms, but opposing them when they approach reelection.

\subsection{The pervasiveness of the protectionist effect of election proximity}

The results presented above show that senators are significantly less likely to support trade liberalization reforms when they are close to facing elections. Is this finding driven solely by the voting behavior of "anti-trade" legislators, i.e. representatives of import-competing constituencies and members of the Democratic party? To address this question, we examine whether inter-generational differences in senators' voting behavior are affected by the trade exposure of their constituencies and their party affiliation.

The results of these estimations are reported in Table 5. Since our previous findings show that there is no statistical difference in behavior between senators belonging to the first and second generation, for ease of exposition we consider these two groups together as the omitted category. In columns (1)-(4), we investigate whether the cyclical voting behavior of senators is driven by their constituencies' trade exposure. To do so, we introduce as controls the interaction terms between the variables Senate 3 and Senate 12 - identifying legislators belonging to the last and the first two generations, respectively - with the variable Export - identifying states in which a majority of workers are employed in export industries.

\footnotetext{
${ }^{30}$ Examples of this type of voting behavior include Senators Brown (CO), Clinton (NY), Dixon (IL), Feinstein $(\mathrm{CA})$, Stabenow (MI), Reed (RI), and Wofford (PA).
} 
Table 5: The protectionist effect of election proximity, by constituency type and party affiliation

\begin{tabular}{|c|c|c|c|c|c|c|c|c|}
\hline & (1) & $(2)$ & (3) & (4) & $(5)$ & (6) & (7) & $(8)$ \\
\hline Senate $3_{i t}$ & $\begin{array}{c}-0.074^{* * *} \\
(0.024)\end{array}$ & $\begin{array}{c}-0.068^{* * *} \\
(0.025)\end{array}$ & $\begin{array}{c}-0.069^{* * *} \\
(0.025)\end{array}$ & $\begin{array}{c}-0.068^{* * *} \\
(0.025)\end{array}$ & $\begin{array}{c}-0.088^{* *} \\
(0.040)\end{array}$ & $\begin{array}{l}-0.080^{*} \\
(0.041)\end{array}$ & $\begin{array}{c}-0.079^{* *} \\
(0.040)\end{array}$ & $\begin{array}{l}-0.078^{*} \\
(0.041)\end{array}$ \\
\hline Senate $_{i t} \mathrm{x}$ Export $_{j t}$ & $\begin{array}{c}0.069 \\
(0.076)\end{array}$ & $\begin{array}{c}0.057 \\
(0.082)\end{array}$ & $\begin{array}{c}0.070 \\
(0.074)\end{array}$ & $\begin{array}{c}0.057 \\
(0.081)\end{array}$ & & & & \\
\hline${\text { Senate } 12_{i t} \text { x Export }}_{j t}$ & $\begin{array}{c}0.117^{* *} \\
(0.048)\end{array}$ & $\begin{array}{c}0.107^{* *} \\
(0.048)\end{array}$ & $\begin{array}{c}0.116^{* * *} \\
(0.045)\end{array}$ & $\begin{array}{c}0.107^{* *} \\
(0.048)\end{array}$ & & & & \\
\hline Senate $_{i t}$ x Democrat ${ }_{i}$ & & & & & $\begin{array}{c}-0.167 * * * \\
(0.063)\end{array}$ & $\begin{array}{c}-0.167 * * * \\
(0.063)\end{array}$ & $\begin{array}{c}-0.165^{* * *} \\
(0.063)\end{array}$ & $\begin{array}{c}-0.173^{* * *} \\
(0.063)\end{array}$ \\
\hline Senate12 $_{i t} \mathrm{x}$ Democrat $_{i}$ & & & & & $\begin{array}{c}-0.180^{* * *} \\
(0.058)\end{array}$ & $\begin{array}{c}-0.164^{* * *} \\
(0.057)\end{array}$ & $\begin{array}{c}-0.159^{* * *} \\
(0.057)\end{array}$ & $\begin{array}{c}-0.172^{* * * *} \\
(0.056)\end{array}$ \\
\hline Democrat $_{i}$ & & $\begin{array}{c}-0.119 * * * \\
(0.040)\end{array}$ & $\begin{array}{c}-0.118^{* * *} \\
(0.040)\end{array}$ & $\begin{array}{c}-0.118^{* * *} \\
(0.040)\end{array}$ & & & & \\
\hline Party as President $i t$ & & $\begin{array}{c}0.069 * * * \\
(0.025)\end{array}$ & $\begin{array}{c}0.069^{* * * *} \\
(0.025)\end{array}$ & $\begin{array}{c}0.068^{* * *} \\
(0.025)\end{array}$ & & & & \\
\hline Female $_{i}$ & & $\begin{array}{l}-0.040 \\
(0.057)\end{array}$ & $\begin{array}{l}-0.042 \\
(0.059)\end{array}$ & $\begin{array}{l}-0.041 \\
(0.058)\end{array}$ & & $\begin{array}{l}-0.035 \\
(0.054)\end{array}$ & $\begin{array}{l}-0.042 \\
(0.057)\end{array}$ & $\begin{array}{l}-0.031 \\
(0.055)\end{array}$ \\
\hline $\operatorname{Age}_{i t}$ & & $\begin{array}{c}-0.005^{* * *} \\
(0.002)\end{array}$ & $\begin{array}{c}-0.005^{* * *} * \\
(0.002)\end{array}$ & $\begin{array}{c}-0.005^{* * *} * \\
(0.002)\end{array}$ & & $\begin{array}{c}-0.005^{* * *} \\
(0.002)\end{array}$ & $\begin{array}{c}-0.005^{* * *} \\
(0.002)\end{array}$ & $\begin{array}{c}-0.005^{* * *} \\
(0.002)\end{array}$ \\
\hline Population $_{j t}$ & & $\begin{array}{c}0.008 \\
(0.015)\end{array}$ & $\begin{array}{c}0.008 \\
(0.015)\end{array}$ & $\begin{array}{c}0.008 \\
(0.015)\end{array}$ & & $\begin{array}{c}0.004 \\
(0.017)\end{array}$ & $\begin{array}{c}0.005 \\
(0.017)\end{array}$ & $\begin{array}{c}0.006 \\
(0.016)\end{array}$ \\
\hline Export Ratio $_{j t}$ & & & & & & $\begin{array}{l}0.103^{*} \\
(0.057)\end{array}$ & $\begin{array}{l}0.139^{* *} \\
(0.060)\end{array}$ & \\
\hline HHI Exports $_{j t}$ & & & $\begin{array}{l}-0.037 \\
(0.203)\end{array}$ & & & & $\begin{array}{l}-0.084 \\
(0.210)\end{array}$ & \\
\hline HHI Imports $_{j t}$ & & & $\begin{array}{c}0.173 \\
(0.438)\end{array}$ & & & & $\begin{array}{c}0.384 \\
(0.498)\end{array}$ & \\
\hline High Skill $_{j t}$ & & & & $\begin{array}{c}-0.607 \\
(1.661)\end{array}$ & & & & $\begin{array}{c}-0.684 \\
(1.622)\end{array}$ \\
\hline Year and state effects & included & included & included & included & included & included & included & included \\
\hline 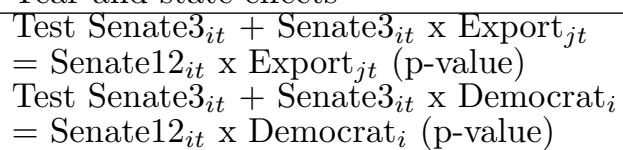 & 0.080 & 0.102 & 0.100 & 0.103 & 0.032 & 0.017 & 0.016 & 0.026 \\
\hline Observations & 1,254 & 1,254 & 1,254 & 1,254 & 1,254 & 1,254 & 1,254 & 1,254 \\
\hline Pseudo $R^{2}$ & 0.28 & 0.31 & 0.31 & 0.31 & 0.30 & 0.31 & 0.31 & 0.31 \\
\hline Log likelihood & -506.30 & -483.89 & -483.65 & -483.77 & -495.65 & -485.83 & -484.73 & -488.92 \\
\hline Predicted probability & 0.83 & 0.84 & 0.84 & 0.84 & 0.83 & 0.84 & 0.84 & 0.83 \\
\hline
\end{tabular}

The table reports marginal effects of probit regressions. The dependent variable, Vote $e_{i j t}$, equals 1 if senator $i$ representing state $j$ votes in favor of trade liberalization in year $t, 0$ otherwise. Standard errors clustered at state level in parenthesis; *** denotes significance at $1 \%$ level; ** $5 \%$ level; * $10 \%$ level. 
We find that, earlier in their mandate, representatives of export constituencies are more willing to support trade liberalization reforms than representatives of import-competing ones (the coefficient of the interaction term Senate 12 x Export is positive and significant). However, this difference disappears at the end of their mandate (the coefficient of the interaction term Senate3 $\mathrm{x}$ Export is positive but not significant). Interestingly, our results show that election proximity reduces support for trade liberalization among representatives of both import-competing constituencies (the coefficient of the variable Senate3 is negative and significant) and export constituencies (the $\chi^{2}$ test at the bottom of the table, comparing the last and the first two generations of senators from export-oriented states, rejects the null hypothesis that the effect is identical). ${ }^{31}$

In columns (5)-(8) we examine instead the role of party affiliation, interacting the two classes of senators with the variable Democrat. The results confirm that members of the Democratic party are less supportive of trade liberalization than those of the Republican party. However, senators from both parties become more protectionist in the last two years of their mandate: inter-generational differences are observed among Republicans (the estimates for Senate3 is negative and significant) as well as Democrats (the $\chi^{2}$ test at the bottom of the table, comparing the last and the first two generations of Democratic senators, rejects the null hypothesis that the effect is identical).

Summarizing, Table 5 shows that election proximity has a pervasive effect, i.e. it deters legislators from supporting trade liberalization reforms, even if they represent constituencies in which most workers are employed in export industries or they belong to the Republican party.

\subsection{The role of re-election incentives}

The results of Tables 2-5 show that election proximity leads legislators to become more protectionist. What drives this result? A natural explanation is represented by electoral incentives. To assess their role, in Table 6 we carry out two falsification exercises: first, we examine the voting behavior of senators who have announced their retirement, and thus do not care about their re-election chances; second, we focus on senators holding safe seats, who have little chance of losing office. If re-election motives are the reason behind the inter-generational differences in voting behavior documented above, we would expect the protectionist effect of election proximity to disappear for senators who are not seeking re-election or hold safe seats.

\footnotetext{
${ }^{31}$ This is the case in two out of four specifications. In the other two, the p-value for the the test is just above the $10 \%$ level.
} 
Table 6: Senators retiring or holding safe seats

\begin{tabular}{|c|c|c|c|c|c|c|c|c|}
\hline & (1) & $(2)$ & $(3)$ & (4) & $(5)$ & (6) & $(7)$ & $(8)$ \\
\hline Senate $3_{i t}$ & $\begin{array}{c}-0.091^{* * *} \\
(0.023)\end{array}$ & $\begin{array}{c}-0.089^{* * *} \\
(0.024)\end{array}$ & $\begin{array}{c}-0.089^{* * *} \\
(0.024)\end{array}$ & $\begin{array}{c}-0.086^{* * *} \\
(0.024)\end{array}$ & $\begin{array}{c}-0.088^{* * *} \\
(0.024)\end{array}$ & $\begin{array}{c}-0.083^{* * *} \\
(0.025)\end{array}$ & $\begin{array}{c}-0.085^{* * *} \\
(0.026)\end{array}$ & $\begin{array}{c}-0.079^{* * *} \\
(0.025)\end{array}$ \\
\hline Senate $_{i t} \mathrm{x}$ Retiring $i t$ & $\begin{array}{c}0.080 \\
(0.065)\end{array}$ & $\begin{array}{l}0.095^{*} \\
(0.049)\end{array}$ & $\begin{array}{l}0.092^{*} \\
(0.050)\end{array}$ & $\begin{array}{c}0.099^{* *} \\
(0.049)\end{array}$ & & & & \\
\hline Senate $12_{i t} \mathrm{x}$ Retiring $i t$ & $\begin{array}{l}-0.122 \\
(0.152)\end{array}$ & $\begin{array}{l}-0.057 \\
(0.144)\end{array}$ & $\begin{array}{l}-0.052 \\
(0.144)\end{array}$ & $\begin{array}{l}-0.058 \\
(0.144)\end{array}$ & & & & \\
\hline $\operatorname{Senate}_{i t}$ x $\mathrm{Safe}_{i t}$ & & & & & $\begin{array}{c}0.116^{* *} \\
(0.058)\end{array}$ & $\begin{array}{c}0.142^{* * *} \\
(0.030)\end{array}$ & $\begin{array}{c}0.145^{* * *} \\
(0.027)\end{array}$ & $\begin{array}{c}0.135^{* * *} \\
(0.043)\end{array}$ \\
\hline Senate $12_{i t} \mathrm{x} \mathrm{Safe}_{i t}$ & & & & & $\begin{array}{c}0.150^{* * * *} \\
(0.028)\end{array}$ & $\begin{array}{c}0.164^{* * *} \\
(0.015)\end{array}$ & $\begin{array}{c}0.166^{* * *} \\
(0.016)\end{array}$ & $\begin{array}{c}0.153^{* * *} \\
(0.025)\end{array}$ \\
\hline Democrat $_{i}$ & & $\begin{array}{c}-0.120^{* * *} \\
(0.040)\end{array}$ & $\begin{array}{c}-0.117^{* * *} \\
(0.041)\end{array}$ & $\begin{array}{c}-0.125^{* * *} \\
(0.039)\end{array}$ & & $\begin{array}{c}-0.124^{* * *} \\
(0.040)\end{array}$ & $\begin{array}{c}-0.121^{* * * *} \\
(0.040)\end{array}$ & $\begin{array}{c}-0.130^{* * * *} \\
(0.039)\end{array}$ \\
\hline Party as President $i t$ & & $\begin{array}{c}0.065^{* * *} \\
(0.024)\end{array}$ & $\begin{array}{c}0.065^{* * *} \\
(0.024)\end{array}$ & $\begin{array}{c}0.067^{* * *} \\
(0.024)\end{array}$ & & $\begin{array}{c}0.055^{* *} \\
(0.026)\end{array}$ & $\begin{array}{c}0.056^{* *} \\
(0.026)\end{array}$ & $\begin{array}{c}0.059^{* *} \\
(0.026)\end{array}$ \\
\hline Female $_{i}$ & & $\begin{array}{l}-0.040 \\
(0.056)\end{array}$ & $\begin{array}{l}-0.045 \\
(0.058)\end{array}$ & $\begin{array}{l}-0.035 \\
(0.057)\end{array}$ & & $\begin{array}{c}0.001 \\
(0.052)\end{array}$ & $\begin{array}{l}-0.003 \\
(0.054)\end{array}$ & $\begin{array}{c}0.008 \\
(0.053)\end{array}$ \\
\hline $\operatorname{Age}_{i t}$ & & $\begin{array}{c}-0.005^{* * *} * \\
(0.002)\end{array}$ & $\begin{array}{c}-0.005^{* * *} \\
(0.002)\end{array}$ & $\begin{array}{c}-0.005^{* * *} \\
(0.002)\end{array}$ & & $\begin{array}{c}-0.005^{* * *} \\
(0.002)\end{array}$ & $\begin{array}{c}-0.005^{* * * *} \\
(0.002)\end{array}$ & $\begin{array}{c}-0.005^{* * * *} \\
(0.002)\end{array}$ \\
\hline Population $_{j t}$ & & $\begin{array}{c}0.007 \\
(0.015)\end{array}$ & $\begin{array}{c}0.007 \\
(0.015)\end{array}$ & $\begin{array}{c}0.008 \\
(0.015)\end{array}$ & & $\begin{array}{c}0.008 \\
(0.014)\end{array}$ & $\begin{array}{c}0.007 \\
(0.015)\end{array}$ & $\begin{array}{c}0.007 \\
(0.015)\end{array}$ \\
\hline Export Ratio $_{j t}$ & & $\begin{array}{l}0.099^{*} \\
(0.053)\end{array}$ & $\begin{array}{c}0.133^{* *} \\
(0.059)\end{array}$ & & & $\begin{array}{c}0.137^{* *} * \\
(0.058)\end{array}$ & $\begin{array}{c}0.164^{* * *} * \\
(0.062)\end{array}$ & \\
\hline HHI Exports E $_{j t}$ & & & $\begin{array}{l}-0.053 \\
(0.205)\end{array}$ & & & & $\begin{array}{c}0.022 \\
(0.222)\end{array}$ & \\
\hline HHI Imports $j t$ & & & $\begin{array}{c}0.407 \\
(0.495)\end{array}$ & & & & $\begin{array}{c}0.514 \\
(0.533)\end{array}$ & \\
\hline High Skill $_{j t}$ & & & & $\begin{array}{l}-0.580 \\
(1.656)\end{array}$ & & & & $\begin{array}{l}-0.549 \\
(1.691)\end{array}$ \\
\hline Year and state effects & included & included & included & included & included & included & included & included \\
\hline 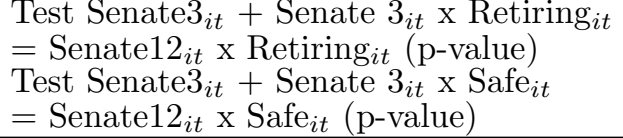 & 0.196 & 0.298 & 0.356 & 0.264 & 0.315 & 0.231 & 0.262 & 0.425 \\
\hline Observations & 1,254 & 1,254 & 1,254 & 1,254 & 1,213 & 1,213 & 1,213 & 1,213 \\
\hline Pseudo $R^{2}$ & 0.28 & 0.32 & 0.32 & 0.31 & 0.28 & 0.32 & 0.32 & 0.31 \\
\hline Log likelihood & -507.68 & -481.60 & -480.68 & -484.46 & -497.31 & -470.84 & -470.06 & -475.73 \\
\hline Predicted probability & 0.83 & 0.84 & 0.84 & 0.83 & 0.82 & 0.83 & 0.83 & 0.83 \\
\hline
\end{tabular}

The table reports marginal effects of probit regressions. The dependent variable, Vote $e_{i j t}$, equals 1 if senator $i$ representing state $j$ votes in favor of trade liberalization in year $t, 0$ otherwise. Standard errors clustered at state level in parenthesis; $* * *$ denotes significance at $1 \%$ level; ** $5 \%$ level; * $10 \%$ level. 
In columns (1)-(4), we examine the impact of election proximity on the voting behavior of retiring senators. To do so, we include interaction terms between the dummies capturing different generations of senators (Senate3 and Senate12) and the dummy Retiring. The negative and significant coefficient for Senate3 captures the protectionist effect of election proximity for senators who are running for re-election. The marginal effects of the interaction terms suggest that retiring senators are more likely to vote in favor of trade reforms. ${ }^{32}$ Crucially, election proximity does not affect their support for trade liberalization: the $\chi^{2}$ tests at the bottom of the table show that retiring senators do not change their voting behavior over their mandates.

The results of Table 6 suggest that the protectionist effect of election proximity is driven by politicians' desire to retain office. Interestingly, two of the trade liberalization votes in our sample (the first approval of fast track in December 1974 and the ratification of the Uruguay Round Agreement in December 1994) occurred in a "lame duck" session (after the November general elections, but before the newly elected senators had taken their seats). In line with the results on retiring senators, none of the defeated senators voted against these bills.

In columns (5)-(8), we perform a similar exercise, interacting Senate3 and Senate12 with the variable Safe, which is equal to one for legislators who were last elected with a margin of victory of at least 60 percentage points (the average margin of victory plus two standard deviations). The positive and significant coefficients on these interaction terms suggest that holding a safe seat increases the likelihood that a senator votes in favor of trade liberalization. Moreover, the tests at the bottom of the table show that senators who are not concerned about losing office do not change their voting behavior on trade reforms when they approach re-election. By contrast, the negative and significant coefficients of Senate3 indicate that election proximity has a protectionist effect on the voting behavior of senators who do not hold safe seats.

The results of Table 6 strongly suggest that the protectionist effect of election proximity is driven by re-election motives: the estimates for the variable Senate3 indicate that, for senators who are running for re-election or whose seats are contested, the probability of supporting trade liberalization is between 10 and 11 percentage points lower in the last two years of their mandate; the tests at the bottom of the table show that this cyclical behavior disappears for senators who are not afraid of losing office, either because they are retiring or because they hold safe seats.

\subsection{Additional robustness checks}

In what follows, we discuss the results of a series of additional estimations to verify the robustness of our findings on the protectionist effect of election proximity.

First, we use a linear probability model to examine the impact of election proximity on sen-

\footnotetext{
${ }^{32}$ The interaction terms between Retiring and Senate 3 is positive and significant in all but the first specification. The interaction terms between Retiring and Senate 12 are insignificant, but this may be due to the fact that senators may decide to retire towards the end of their terms.
} 
ators' voting behavior. This approach is not ideal when the dependent variable is dichotomous, since in such case the residuals are, by construction, not homescedastic. Moreover, the predicted values are not guaranteed to fall within the unit interval, which should instead be the case in order to interpret them as probabilities. The advantage of the linear probability model lies in the fact that we can directly interpret the estimated coefficients as the marginal effects of each explanatory variable. Table 7 reports our results focusing on the voting behavior of different legislators. ${ }^{33}$ These findings confirm that election proximity has a protectionist effect on senators' support for trade reforms (the dummy variable Senate3 is negative and highly significant in all specifications). The point estimates for Senate3 are very similar to the marginal effects computed using the probit model (see Table 3).

Table 7: The protectionist effect of election proximity, linear probability model

\begin{tabular}{|c|c|c|c|c|c|c|c|}
\hline & (1) & $(2)$ & (3) & (4) & $7(5)$ & (6) & " (7) \\
\hline Senate $3_{i t}$ & $\begin{array}{c}-0.066^{* * *} \\
(0.021)\end{array}$ & $\begin{array}{c}-0.064^{* * *} \\
(0.021)\end{array}$ & $\begin{array}{c}-0.064^{* * *} \\
(0.019)\end{array}$ & $\begin{array}{c}-0.057^{* * *} \\
(0.020)\end{array}$ & $\begin{array}{c}-0.058^{* * *} \\
(0.020)\end{array}$ & $\begin{array}{c}-0.054^{* * *} \\
(0.020)\end{array}$ & $\begin{array}{c}-0.062^{* * *} \\
(0.022)\end{array}$ \\
\hline Democrat $_{i}$ & & & & $\begin{array}{c}-0.114^{* * *} \\
(0.037)\end{array}$ & $\begin{array}{c}-0.108^{* * * *} \\
(0.038)\end{array}$ & $\begin{array}{c}-0.118^{* * *} \\
(0.037)\end{array}$ & $\begin{array}{r}-0.071^{*} \\
(0.039)\end{array}$ \\
\hline Party as President $i t$ & & & & $\begin{array}{c}0.063^{* * *} \\
(0.019)\end{array}$ & $\begin{array}{c}0.063^{* * *} \\
(0.019)\end{array}$ & $\begin{array}{c}0.065^{* * *} \\
(0.019)\end{array}$ & $\begin{array}{c}0.058^{* * *} \\
(0.019)\end{array}$ \\
\hline Female $_{i}$ & & & & $\begin{array}{l}-0.014 \\
(0.041)\end{array}$ & $\begin{array}{l}-0.019 \\
(0.043)\end{array}$ & $\begin{array}{l}-0.011 \\
(0.043)\end{array}$ & $\begin{array}{l}-0.005 \\
(0.038)\end{array}$ \\
\hline $\operatorname{Age}_{i t}$ & & & & $\begin{array}{c}-0.004^{* * *} \\
(0.001)\end{array}$ & $\begin{array}{c}-0.004^{* * * *} \\
(0.001)\end{array}$ & $\begin{array}{c}-0.004^{* * *} \\
(0.001)\end{array}$ & $\begin{array}{c}-0.004^{* * *} \\
(0.001)\end{array}$ \\
\hline Population $_{j t}$ & & & & $\begin{array}{c}0.007 \\
(0.014)\end{array}$ & $\begin{array}{c}0.005 \\
(0.013)\end{array}$ & $\begin{array}{c}0.007 \\
(0.014)\end{array}$ & $\begin{array}{c}0.011 \\
(0.014)\end{array}$ \\
\hline Export ratio $_{j t}$ & & & & $\begin{array}{c}0.075^{* *} \\
(0.035)\end{array}$ & $\begin{array}{c}0.113^{* * *} \\
(0.041)\end{array}$ & & $\begin{array}{c}0.080^{* *} \\
(0.036)\end{array}$ \\
\hline $\mathrm{HHI}_{\text {exports }}{ }_{j t}$ & & & & & $\begin{array}{c}0.055 \\
(0.190)\end{array}$ & & \\
\hline HHI imports $_{j t}$ & & & & & $\begin{array}{l}0.741 \\
(0.450)\end{array}$ & & \\
\hline High skill $_{j t}$ & & & & & & $\begin{array}{l}-0.144 \\
(1.374)\end{array}$ & \\
\hline Labor contributions $_{i t}$ & & & & & & & $\begin{array}{c}-0.054^{* * *} \\
(0.015)\end{array}$ \\
\hline Corporate contributions $_{i t}$ & & & & & & & $\begin{array}{c}0.016^{* * * *} \\
(0.004)\end{array}$ \\
\hline Year effects & included & & included & included & included & included & included \\
\hline State effects & & included & included & included & included & included & included \\
\hline Observations & 1,331 & 1,331 & 1,331 & 1,331 & 1,331 & 1,331 & 1,331 \\
\hline$R^{2}$ & 0.09 & 0.20 & 0.29 & 0.32 & 0.32 & 0.32 & 0.33 \\
\hline
\end{tabular}

The dependent variable, Vote $_{i j t}$, equals 1 if senator $i$ representing state $j$ votes in favor of trade liberalization in year $t, 0$ otherwise. The table reports coefficients of a linear probability model, with standard errors clustered at state level in parenthesis. ${ }^{* * *}$ denotes significance at $1 \%$ level; ${ }^{* *} 5 \%$ level; $* 10 \%$ level.

Second, it has been argued that party discipline is stronger for votes that only pass by a narrow margin (Snyder and Groseclose 2000). If party discipline is very strong, a senator's voting behavior may not be affected by how close he or she is to facing re-election. In Table 8 , we investigate

\footnotetext{
${ }^{33}$ Recall that in Table 4 we already reported the results of a linear probability model when examining the voting behavior of individual senators. In that setting, using the linear probability estimator is clearly appealing, since probit suffers from the incidental parameters problem and conditional logit does not allow us to compute marginal effects to interpret the magnitude of the effects of the regressors.
} 
whether the protectionist effect of election proximity applies to both close and lopsided votes, comparing both the voting behavior of different senators (columns 1-4) and of individual senators over time (columns 5-8). Columns (1) and (2) reproduce the results of the specifications in columns (4) and (5) of Table 3 when we restrict the analysis to close votes, for which the margin of passage was below the mean of the entire sample (0.54). In columns (3)-(4), we focus instead on those votes that passed with a broader margin. For both subsamples, we find evidence of a protectionist effect of election proximity: the estimates for Senate3 are negative and significant, indicating that senators are less supportive of trade liberalization in the last two years of their terms. Interestingly, the coefficients for the variables Democrat and Party as President are only significant in columns (1) and (2), suggesting that party discipline may only matter for contested decisions. In columns (5)-(8), we exploit within-senator variation in support for trade reforms to examine the effect of election proximity for close and lopsided votes. In all but one specification, the estimates for Senate3 are negative and significant, confirming the protectionist effect of election proximity.

Table 8: Close vs lopsided votes

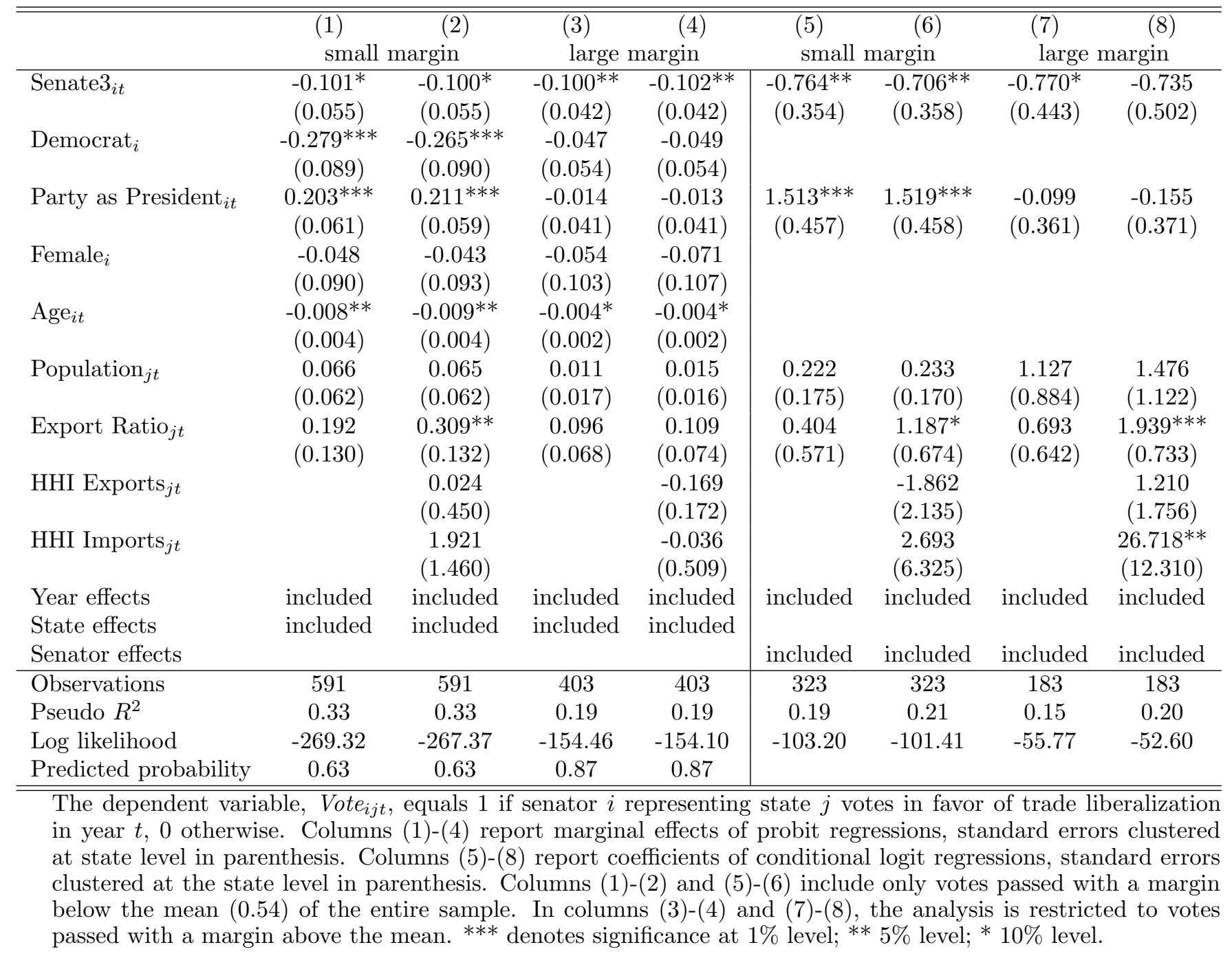


Table 9: Additional political controls

\begin{tabular}{|c|c|c|c|c|c|c|c|c|}
\hline & $(1)$ & $(2)$ & $(3)$ & $(4)$ & $(5)$ & $(6)$ & $(7)$ & $(8)$ \\
\hline Senate $3_{i t}$ & $\begin{array}{c}-0.081^{* * *} \\
(0.024)\end{array}$ & $\begin{array}{c}-0.078^{* * *} \\
(0.024)\end{array}$ & $\begin{array}{c}-0.088^{* * *} \\
(0.023)\end{array}$ & $\begin{array}{c}-0.079^{* * *} \\
(0.024)\end{array}$ & $\begin{array}{c}-0.727^{* * *} \\
(0.182)\end{array}$ & $\begin{array}{c}-0.714^{* * *} \\
(0.185)\end{array}$ & $\begin{array}{c}-0.747^{* * *} \\
(0.198)\end{array}$ & $\begin{array}{c}-0.735^{* * *} \\
(0.184)\end{array}$ \\
\hline Democrat $_{i}$ & $\begin{array}{c}-0.124^{* * *} \\
(0.039)\end{array}$ & $\begin{array}{c}-0.121^{* * *} \\
(0.040)\end{array}$ & $\begin{array}{c}-0.115^{* * *} \\
(0.037)\end{array}$ & $\begin{array}{c}-0.120^{* * *} \\
(0.040)\end{array}$ & & & & \\
\hline Party as President $_{i t}$ & $\begin{array}{c}0.066^{* * *} \\
(0.024)\end{array}$ & $\begin{array}{c}0.062^{* *} \\
(0.025)\end{array}$ & $\begin{array}{c}0.060^{* *} \\
(0.023)\end{array}$ & $\begin{array}{c}0.068^{* * *} \\
(0.025)\end{array}$ & $\begin{array}{c}0.651^{* * *} \\
(0.237)\end{array}$ & $\begin{array}{c}0.622^{* * *} \\
(0.235)\end{array}$ & $\begin{array}{c}0.623^{* *} \\
(0.248)\end{array}$ & $\begin{array}{c}0.671^{* * *} \\
(0.243)\end{array}$ \\
\hline Female $_{i}$ & $\begin{array}{l}-0.022 \\
(0.055)\end{array}$ & $\begin{array}{l}-0.035 \\
(0.057)\end{array}$ & $\begin{array}{l}-0.025 \\
(0.053)\end{array}$ & $\begin{array}{l}-0.049 \\
(0.057)\end{array}$ & & & & \\
\hline $\operatorname{Age}_{i t}$ & $\begin{array}{c}-0.008^{* * *} \\
(0.002)\end{array}$ & $\begin{array}{c}-0.006^{* * *} \\
(0.002)\end{array}$ & $\begin{array}{c}-0.005^{* * *} \\
(0.002)\end{array}$ & $\begin{array}{c}-0.005^{* * * *} \\
(0.002)\end{array}$ & & & & \\
\hline Population $_{j t}$ & $\begin{array}{c}0.009 \\
(0.015)\end{array}$ & $\begin{array}{c}0.006 \\
(0.016)\end{array}$ & $\begin{array}{c}0.008 \\
(0.015)\end{array}$ & $\begin{array}{c}0.008 \\
(0.015)\end{array}$ & $\begin{array}{c}0.336^{* *} \\
(0.144)\end{array}$ & $\begin{array}{c}0.299^{*} \\
(0.155)\end{array}$ & $\begin{array}{c}0.375^{* * *} \\
(0.133)\end{array}$ & $\begin{array}{c}0.334^{* *} \\
(0.143)\end{array}$ \\
\hline Export Ratio $_{j t}$ & $\begin{array}{c}0.100^{*} \\
(0.053)\end{array}$ & $\begin{array}{c}0.100^{*} \\
(0.054)\end{array}$ & $\begin{array}{c}0.084^{*} \\
(0.049)\end{array}$ & $\begin{array}{c}0.102^{*} \\
(0.055)\end{array}$ & $\begin{array}{c}0.738 \\
(0.514)\end{array}$ & $\begin{array}{c}0.743 \\
(0.498)\end{array}$ & $\begin{array}{c}0.649 \\
(0.469)\end{array}$ & $\begin{array}{c}0.721 \\
(0.498)\end{array}$ \\
\hline Tenure $_{i t}$ & $\begin{array}{c}0.005^{* *} \\
(0.002)\end{array}$ & & & & $\begin{array}{c}-0.695 \\
(0.708)\end{array}$ & & & \\
\hline Incumbent $_{i t}$ & & $\begin{array}{c}0.038 \\
(0.036)\end{array}$ & & & & $\begin{array}{c}0.281 \\
(0.319)\end{array}$ & & \\
\hline Appropriations committee $_{i t}$ & & & $\begin{array}{c}0.053^{*} \\
(0.028)\end{array}$ & & & & $\begin{array}{c}0.582 \\
(0.490)\end{array}$ & \\
\hline Finance committee $_{i t}$ & & & $\begin{array}{c}0.143^{* * *} \\
(0.020)\end{array}$ & & & & $\begin{array}{c}1.669^{* * * *} \\
(0.464)\end{array}$ & \\
\hline Presidential aspirations $_{i t}$ & & & & $\begin{array}{c}0.058 \\
(0.043)\end{array}$ & & & & $\begin{array}{c}0.267 \\
(0.590)\end{array}$ \\
\hline Year effects & included & included & included & included & included & included & included & included \\
\hline State effects & included & included & included & included & & & & \\
\hline Senator effects & & & & & included & included & included & included \\
\hline Observations & 1,254 & 1,254 & 1,254 & 1,254 & 754 & 754 & 754 & 754 \\
\hline Pseudo $R^{2}$ & 0.32 & 0.32 & 0.33 & 0.32 & 0.23 & 0.23 & 0.24 & 0.23 \\
\hline Log likelihood & -479.95 & -482.06 & -469.78 & -482.17 & -246.80 & -246.54 & -243.01 & -246.86 \\
\hline Predicted probability & 0.84 & 0.84 & 0.84 & 0.84 & & & & \\
\hline
\end{tabular}

The dependent variable, Vote $_{i j t}$, equals 1 if senator $i$ representing state $j$ votes in favor of trade liberalization in year $t, 0$ otherwise. Columns (1)-(4) report marginal effects of probit regressions, standard errors clustered at state level in parenthesis; Columns (5)-(8) report coefficients of conditional logit regressions, standard errors clustered at the state level in parenthesis; $* * *$ denotes significance at $1 \%$ level; ** $5 \%$ level; * $10 \%$ level. 
Third, in Table 9 we include additional controls to account for other potential drivers of senators' voting behavior on trade reforms. In particular, we examine the role of Tenure (columns 1 and 5), whether a senator is an Incumbent (columns 2 and 6), belongs to the Appropriations committee or Finance committee (columns 3 and 7), or has Presidential aspirations (columns 4 and 8). In the specifications reported in columns (1)-(4), we examine the effect of election proximity by comparing the voting behavior of different senators on the same bill. In columns (5)-(8) we focus instead on the behavior of individual legislators on different bills.

Incumbency and presidential aspirations do not appear to play a significant role, while longer tenure and membership in the Appropriation and Finance committees are associated (at least in some specifications) with increased support for trade liberalization reforms. ${ }^{34}$ More importantly, including these additional controls does not change our main result, i.e. senators belonging to the last generation are significantly more protectionist than senators belonging to the first and second generation. ${ }^{35}$

Our results were also unaffected when we introduced additional controls for legislators' constituencies (i.e. real GDP per capita, unemployment rate, and the share of the population over 65 ), used alternative measures to proxy for legislators' ideology and constituencies' trade policy interests, or restricted the analysis to different subsets of trade liberalization bills (see Section 4.3 for more details). The results of these estimations are available upon request.

\section{Discussion}

The findings presented in the previous two sections show that the political horizon of legislators crucially affects their voting behavior on trade liberalization reforms. In particular, i) House Representatives are generally more protectionist than Senate members (Table 1), but intercameral differences disappear for the last generation of senators, who are up for re-election at the same time as House members (Table 2); ii) election proximity reduces senators' support for trade liberalization, a result that holds both when comparing different legislators voting on the same bill (Table 3) and individual legislators voting on different bills (Table 4); iii) the protectionist effect of election proximity is pervasive (Table 5): it applies not only to senators who generally oppose trade liberalization (members of the Democratic party and representatives of importcompeting constituencies), but also to more pro-trade senators (members of the Republican party and representatives of export-oriented constituencies); iv) inter-generational differences disappear only for senators who are not concerned about losing office, either because they have

\footnotetext{
${ }^{34}$ To verify whether senators with longer tenure are less likely to change their voting behavior on trade reforms when they approach re-election, we have tried interacting the variable Senate 3 with a dummy variable equal to 1 if Tenure $_{i t}$ was higher than a certain cutoff (the mean level of the variable, the 75th, 90th and 95th percentile). We found that the protectionist effect of election proximity disappears only for very high thresholds (above $90 \%$ ).

${ }^{35}$ Our results are also unaffected when including all these controls together.
} 
decided to step down or because they hold very safe seats (Table 6).

Existing theories on the political economy of trade policy cannot readily explain these findings, since they do not consider the role of term length and election proximity. In this section, we discuss possible mechanisms that could explain the observed patterns in congressmen's voting behavior on trade reforms.

The fact that politicians are less supportive of trade liberalization reforms when they are close to re-election suggests the existence of a protectionist bias in trade policy. The existence of such a bias is a well known stylized fact (Rodrik 1995) and several explanations have been proposed for it. In models of majoritarian electoral politics, protectionist policies may simply arise if the median voter is an unskilled worker and there is no way to compensate the losers from trade liberalization (Mayer 1984). In this case, the protectionist stance of politicians may simply reflect the interests of the majority of the electorate. A protectionist bias can also arise if preferences exhibit loss aversion, implying that individuals place a larger welfare weight on the losses than on the gains from trade liberalization (Freund and Ozden 2008; Tovar 2009). Asymmetries in information can also play a role: voters may prefer protection over free trade because they are better informed about the trade barriers that help them as producers than those that hurt them as consumers (Ponzetto 2011). As it turns out, opinion polls show that most Americans oppose trade liberalization (e.g. Scheve and Slaughter 2001; Mayda and Rodrik 2005). Interestingly, however, they also reveal that only a minority of respondents consider trade policy as a salient issue, which affects their voting decisions. ${ }^{36}$ As a result, rather than responding to the interests of the median voter, politicians may be accountable to a minority of voters who care intensely about trade policy. ${ }^{37}$

A protectionist bias in trade policy can explain why politicians are often reluctant to support trade liberalization. By itself, however, this does not provide a rationale for the protectionist effect of election proximity. A recency bias in voters' behavior can instead explain why politicians are more likely to oppose trade reforms when they are close to re-election. If voters attach more weight to recent rather than earlier performance of their representatives, the policy choices of incumbent politicians at the end of their terms will have a bigger impact on their ability to retain office. ${ }^{38}$

\footnotetext{
${ }^{36}$ In the 2006 Cooperative Congressional Election Study (CCES), a random subsample of respondents were asked to rate the following issues in terms of importance: education, the environment, health care, immigration, international trade, social security, taxes, and terrorism (Campbell 2007). Specifically, they were asked "In determining whom you vote for, how important are the following issues?". The possible replies were "Extremely", "Very", "Somewhat", and "Not". Only $16.10 \%$ of the respondents considered trade as an "Extremely" important issue in determining their voting decisions. Interestingly, $66.24 \%$ of the individuals who rated international trade as being "Extremely" important for their voting decisions were in favor of new limits on imports.

${ }^{37}$ List and Sturm (2006) describe a political agency model in which politicians use secondary policies to attract single-issue voters. Bouton, Conconi, Pino, and Zanardi (2013) describe a probabilistic voting model in which politicians may pander to the interests of a vocal minority on an issue which the rest of the electorate cares less intensely about.

${ }^{38}$ The disproportionate salience of recent stimuli or observations is one of the key cognitive biases identified
} 
Note that, if politicians were only office motivated, they would not alter their voting behavior throughout their mandates, even if voters are protectionist and suffer from a recency bias. To explain our findings, a third element is needed: politicians must face a tradeoff between their policy preferences and their re-election motives. This could be the case, for example, if they are more supportive than citizens of trade liberalization reforms because they are better informed about their long-run benefits. Combing this tradeoff with the protectionist and recency biases can explain why politicians "flip flop" on trade policy, supporting trade liberalization reforms earlier in their terms, but opposing them when they approach re-election.

\section{Conclusions}

This paper shows that electoral incentives play an important role in shaping legislators' support for trade liberalization reforms. Our analysis exploits the institutional features of the U.S. Congress - in which House and Senate members serve respectively two- and six-year terms, and one third of senators face elections every two years - to examine the impact of term length and election proximity on congressmen's voting behavior on trade liberalization reforms.

We show that House representatives are more protectionist than members of the Senate. However, this difference disappears for the last generation of senators, who face elections at the same time as House members. This finding provides an explanation for the observed intercameral differences in votes on trade policy: these are not driven by differences in constituency size or by unobserved characteristics of legislators correlated with their trade stance; rather, senators are generally more supportive of trade liberalization reforms because they serve longer mandates and are thus less responsive to short-term electoral pressure. ${ }^{39}$

When restricting our attention to the upper house, we find that the last generation is more protectionist than the previous two: senators who are in the last two years of their terms are less likely to support trade liberalization than senators who are further away from re-election. This result holds both when comparing the behavior of different legislators voting on the same bill, and the behavior of the same legislator over time. It is also robust to the inclusion of a large set of controls for congressmen and their constituencies, and the use of different econometric methodologies. We also show that calendar effects are pervasive: all senators, even those representing export-oriented constituencies, in which a majority of voters should benefit from trade

in behavioral economics, affecting belief formation, decision making, and human behavior in general (Lee 1971). The idea that voters suffer from a recency bias, following the "what have you done for me lately?" principle has been emphasized by a large literature in political science (e.g. Nordhaus 1975; Fiorina 1981; Weingast, Shepsle, and Johnsen 1981; Ferejohn 1986). Empirical and experimental evidence provides strong support for the existence of such bias (e.g. Lewis-Beck and Stegmaier 2000; Huber, Hill, and Lenz 2012).

${ }^{39}$ This finding is reminiscent of arguments raised by the founding fathers of the United States. In the Federalist (63), Madison (1788) championed the creation of the Senate, as "an additional body in the legislative department" with "sufficient permanency" to best deal with long-term policy decisions. 
liberalization, take a more protectionist stance as they approach re-election. Inter-generational differences disappear only for senators who hold very safe seats or are retiring, suggesting that the protectionist effect of election proximity is driven by the fear of losing office.

Our analysis calls for new theoretical models to shed light on the mechanisms through which electoral incentives affect policymakers' voting behavior. In particular, existing models in the political economy of trade cannot readily explain our empirical findings, since they do not examine the role of term length and election proximity.

Another avenue for future research is to examine whether policymakers' horizon affects their voting behavior on other policy issues. Recent work by Bouton, Conconi, Pino, and Zanardi (2013) and Conconi, Pino, and Zanardi (2013) shows that, when U.S. senators approach reelection, they are more likely to take a pro-gun stance when voting on gun control regulations and a green stance when voting on environmental policies. Like trade, gun control and the environment are "secondary" policy issues, which do not shape the decisions of most voters. It would be interesting to examine whether election proximity affects congressmen's voting behavior on "frontline" policy issues, which are salient to a majority of the electorate (e.g. taxation, education, health).

\section{References}

Alesina, A. and A. Drazen (1991). Why are stabilizations delayed? American Economic Review 81, 1170-1188.

Amacher, R. C. and W. J. Boyes (1978). Cycles in senatorial voting behavior: Implications for the optimal frequency of elections. Public Choice 33, 5-13.

Baldwin, R. (1989). The political economy of trade policy. Journal of Economic Perspectives 3, 119-135.

Baldwin, R. E. and C. S. Magee (2000). Is trade policy for sale? Congressional voting on recent trade bills. Public Choice 105, 79-101.

Bernhard, W. and B. R. Sala (2006). The remaking of an American Senate: The 17th amendment and ideological responsiveness. Journal of Politics 68, 345-357.

Blonigen, B. A. and D. N. Figlio (1998). Voting for protection: Does direct foreign investment influence legislator behavior? American Economic Review 88, 1002-1014.

Bouton, L., P. Conconi, F. J. Pino, and M. Zanardi (2013). Guns and votes. CPER working paper 9726.

Campbell, D. (2007). Cooperative Congressional Election Study, 2006.

Conconi, P., G. Facchini, and M. Zanardi (2012). Fast track authority and international trade negotiations. American Economic Journal: Economic Policy 4, 146-189. 
Conconi, P., F. J. Pino, and M. Zanardi (2013). The greening effect of elections. Mimeo, Université Libre de Bruxelles.

Dal Bo, E. and M. Rossi (2011). Term length and political performance. Review of Economic Studies 78, 1237-1263.

Dewatripont, M. and G. Roland (1995). The design of reform packages under uncertainty. American Economic Review 85, 1207-1223.

Dutt, P. and D. Mitra (2002). Endogenous trade policy through majority voting: An empirical investigation. Journal of International Economics 58, 107-133.

Facchini, G. and M. F. Steinhardt (2011). What drives U.S. immigration policy? Evidence from congressional roll call votes. Journal of Public Economics 95, 734-743.

Feenstra, R. C. (1996). U.S. imports, 1972-1994: Data and concordances. NBER Working Paper 5515.

Feenstra, R. C. (1997). U.S. exports, 1972-1994, with state exports and other U.S. data. NBER Working Paper 5990.

Feenstra, R. C., J. Romalis, and P. K. Schott (2002). U.S. imports, exports, and tariff data, 1989-2001. NBER Working Paper 9387.

Ferejohn, J. (1986). Incumbent performance and electoral control. Public Choice 50, 5-25.

Fernandez, R. and D. Rodrik (1991). Resistance to reform: Status quo bias in the presence of individual specific uncertainty. American Economic Review 81, 1146-1155.

Fiorina, M. P. (1981). Retrospective voting in American national elections. New Haven, CT: Yale University Press.

Freund, C. and C. Ozden (2008). Trade policy and loss aversion. American Economic Review 98, 1675-1691.

Gawande, K. and U. Bandyopadhyay (2000). Is protection for sale? Evidence on the Grossman-Helpman theory of endogenous protection. Review of Economics and Statistics 82, 139-152.

Glazer, A. and M. Robbins (1985). How elections matter: A study of U.S. senators. Public Choice 46, 163-172.

Goldberg, P. K. and G. Maggi (1999). Protection for sale: An empirical investigation. American Economic Review 89(5), 1135-55.

Grossman, G. M. and E. Helpman (1994). Protection for sale. American Economic Review 84 , 833-850.

Grossman, G. M. and E. Helpman (1995). Trade wars and trade talks. Journal of Political Economy 103, 675-708.

Grossman, G. M. and E. Helpman (2005). A protectionist bias in majoritarian politics. Quarterly Journal of Economics 120, 1239-1282. 
Hauk, W. (2011). Protection with many sellers: An application to legislatures with malapportionment. Economics 8 Politics 23, 313-344.

Hiscox, M. J. (2004). Commerce, coalitions, and factor mobility: Evidence from congressional votes on trade legislation. American Political Science Review 96, 593-608.

Huber, G. A., S. J. Hill, and G. S. Lenz (2012). Sources of bias in retrospective decision making: Experimental evidence on voters' limitations in controlling incumbents. American Political Science Review 106, 720-741.

Karol, D. (2007). Does constituency size affect elected officials' trade policy preferences? Journal of Politics 69, 483-494.

Lee, W. (1971). Decision theory and human behavior. New York: Wiley.

Leip, D. (2008). Dave Leip's atlas of U.S. presidential elections.

Levitt, S. D. (1996). How do senators vote? Disentangling the role of voters' preferences, party affiliation and senators ideology. American Economic Review 86, 425-441.

Lewis-Beck, M. S. and M. Stegmaier (2000). Economic determinants of electoral outcomes. Annual Review of Political Science 3, 183-219.

List, J. A. and D. M. Sturm (2006). How elections matter: Theory and evidence from environmental policy. Quarterly Journal of Economics 121, 1249-1281.

Madison, J. (1788). Federalist Paper 63. In J. Jay, A. Hamilton, and J. Madison (Eds.), The Federalist or the new Constitution. London: Everyman Edition.

Magee, S. P., W. A. Brock, and L. Young (1989). Black Hole Tariffs and Endogenous Policy Theory: Political Economy in General Equilibrium. New York: Cambridge University Press.

Maggi, G. and A. Rodriguez-Clare (1998). The value of trade agreements in the presence of political pressure. Journal of Political Economy 106, 574-601.

Mayda, A. M. and D. Rodrik (2005). Why are some people (and countries) more protectionist than others? European Economic Review 49, 1393-1430.

Mayer, W. (1984). Endogenous tariff formation. American Economic Review 74, 970-985.

Mian, A., A. Sufi, and F. Trebbi (2010). The political economy of the U.S. mortgage deafult crisis. American Economic Review 100, 1967-1998.

Mitra, D. (1999). Endogenous lobby formation and endogenous protection: A long-run model of trade policy determination. American Economic Review 89(5), 1116-34.

Mitra, D., D. D. Thomakos, and M. A. Ulubaşoğlu (2002). Protection for sale in a developing country: Democracy versus dictatorship. Review of Economics and Statistics 84, 497-508.

Nordhaus, W. D. (1975). The political business cycle. Review of Economic Studies 42, 169182. 
Overby, L. M. and L. C. Bell (2004). Rational behavior or the norm of cooperation? Filibustering among retiring senators. Journal of Politics 66, 906-924.

Peltzman, S. (1985). An economic interpretation of the history of congressional voting in the twentieth century. American Economic Review 75, 656-675.

Ponzetto, G. A. M. (2011). Heterogeneous information and trade policy. CEPR discussion paper 8726 .

Poole, K. T. and H. Rosenthal (1997). A political-economic history of roll call voting. New York: Oxford University Press.

Poole, K. T. and H. Rosenthal (2001). D-nominate after 10 years: A comparative update to congress: A political-economic history of roll-call voting. Legislative Studies Quarterly 26, $5-29$.

Rodrik, D. (1995). Political Economy of trade policy. In G. M. Grossman and K. Rogoff (Eds.), Handbook of International Economics, Volume 3, pp. 1457-1494. Amsterdam and New York: North Holland.

Rogoff, K. (1990). Equilibrium political business cycles. American Economic Review 80, $21-$ 36.

Rogoff, K. and A. Sibert (1988). Elections and macroeconomic policy cycles. Review of Economic Studies 55, 1-16.

Scheve, K. and M. Slaughter (2001). What determines individual trade-policy preferences? Journal of International Economics 54, 267-292.

Snyder, J. M. and T. Groseclose (2000). Party influence in congressional roll-call voting. American Journal of Political Science 44, 193-211.

Stewart, C. I. and T. Groseclose (1999). The value of committee seats in the United States Senate, 1947-91. American Journal of Political Science 43, 963-973.

Swift, E. K., R. G. Brookshire, D. T. Canon, E. C. Fink, J. R. Hibbing, B. D. Humes, M. J. Malbin, and K. C. Martis (2000). Database of congressional historical statistics [computer file]. Ann Arbor, MI: Inter-university Consortium for Political and Social Research.

Thomas, M. (1985). Election proximity and senatorial roll call voting. American Journal of Political Science 29, 96-111.

Titiunik, R. (2008). Drawing your senator from a jar: Term length and legislative behavior. Mimeo, University of California, Berkeley.

Tovar, P. (2009). The effects of loss aversion on trade policy: Theory and evidence. Journal of International Economics 78, 154-167.

Weingast, B. R., K. A. Shepsle, and C. Johnsen (1981). The political economy of benefits and costs: A neoclassical approach to distributive politics. Journal of Political Economy 89, 642-664. 
Table A-1: Votes on trade liberalization bills

\begin{tabular}{|c|c|c|c|}
\hline Bill & Description & Vote in House & Vote in Senate \\
\hline H.R. 10710 & First approval of fast track authority & Dec. 11,1973 & Dec. 20,1974 \\
\hline Trade Act of 1974 & $\begin{array}{l}\text { Other provisions: escape clause, antidumping, countervailing duties, } \\
\text { trade adjustment assistance, GSP }\end{array}$ & $(272-140)$ & $(72-4)$ \\
\hline H.R. 4537 & Approval of Tokyo Round Agreements & July 11,1979 & July 23,1979 \\
\hline Trade Agreements Act of 1979 & Other provisions: extension of fast track authority & $(395-7)$ & $(90-4)$ \\
\hline H.R. 4848 & Approval of fast track authority & July 13,1988 & Aug. 3, 1988 \\
\hline $\begin{array}{l}\text { Omnibus Trade and } \\
\text { Competitiveness Act }\end{array}$ & $\begin{array}{l}\text { Other provisions: strengthening of unilateral trade retaliation instruments, } \\
\text { authority of USTR }\end{array}$ & $(376-45)$ & $(85-11)$ \\
\hline H.R. 5090 & Approval of free trade area between United States and Canada (CUSFTA) & $\begin{array}{l}\text { Aug. } 9,1988 \\
\quad(366-40)\end{array}$ & $\begin{array}{l}\text { Sept. } 19,1988 \\
\quad(83-9)\end{array}$ \\
\hline H.Res. 101/S.Res. 78 & Disapproval of extension of fast track authority & $\begin{array}{l}\text { May } 23,1991 \\
(192-231)\end{array}$ & $\begin{array}{c}\text { May } 24,1991 \\
(36-59)\end{array}$ \\
\hline H.R. 1876 & Extension of fast track authority & $\begin{array}{c}\text { June } 22,1993 \\
(295-126)\end{array}$ & $\begin{array}{c}\text { June } 30,1993 \\
(76-16)\end{array}$ \\
\hline H.R. 3450 & Approval of free trade area between United States, Canada and Mexico (NAFTA) & $\begin{array}{l}\text { Nov. } 17,1993 \\
\quad(234-200)\end{array}$ & $\begin{array}{l}\text { Nov. } 20,1993 \\
\quad(61-38)\end{array}$ \\
\hline H.R. 5110 & Approval of Uruguay Round Agreements & $\begin{array}{l}\text { Nov. } 29,1994 \\
\quad(288-146)\end{array}$ & $\begin{array}{c}\text { Dec. } 1,1994 \\
(76-24)\end{array}$ \\
\hline H.R. 2621 & Approval of fast track authority (denied) & $\begin{array}{c}\text { Sept. } 25,1998 \\
(180-243)\end{array}$ & \\
\hline $\begin{array}{c}\text { H.R. } 3009 \\
\text { Trade Act of } 2002\end{array}$ & $\begin{array}{l}\text { Approval of fast track authority } \\
\text { Other provisions: Andean Trade Preference Act, trade adjustment } \\
\text { assistance, GSP }\end{array}$ & $\begin{array}{c}\text { July } 27,2002 \\
(215-212)\end{array}$ & $\begin{array}{l}\text { Aug. 1, } 2002 \\
(64-34)\end{array}$ \\
\hline H.R. 2738 & Approval of free trade area between United States and Chile & $\begin{array}{l}\text { July } 24,2003 \\
\quad(270-156)\end{array}$ & $\begin{array}{l}\text { July } 31,2003 \\
\quad(65-32)\end{array}$ \\
\hline H.R. 2739 & Approval of free trade area between United States and Singapore & $\begin{array}{c}\text { July } 24,2003 \\
(272-155)\end{array}$ & $\begin{array}{c}\text { July } 31,2003 \\
(66-32)\end{array}$ \\
\hline H.R. 4759 & Approval of free trade area between United States and Australia & $\begin{array}{c}\text { July } 14,2004 \\
(314-109)\end{array}$ & $\begin{array}{c}\text { July } 15,2004 \\
(80-16)\end{array}$ \\
\hline H.R. $4842 /$ S. 2677 & Approval of free trade area between United States and Morocco & $\begin{array}{c}\text { July } 22,2004 \\
(323-99)\end{array}$ & $\begin{array}{c}\text { July } 21,2004 \\
(85-13)\end{array}$ \\
\hline H.R. 3045 & $\begin{array}{l}\text { Approval of free trade area between United States, Dominican Republic, } \\
\text { Costa Rica, El Salvador, Honduras, Guatemala, and Nicaragua (DR-CAFTA) }\end{array}$ & $\begin{array}{l}\text { July } 28,2005 \\
\quad(217-215)\end{array}$ & $\begin{array}{l}\text { July } 28,2005 \\
\quad(55-45)\end{array}$ \\
\hline
\end{tabular}

Notes: Only final passage votes are reported. With the exception of the votes in 1991, the first (second) number in parenthesis refers to votes in favor of the bill (against it). The Senate did not vote on the bill of 1998, since the House had already rejected it. 
Table A-2: Definition of variables and sources

\begin{tabular}{|c|c|c|}
\hline Variable & Definition & Source \\
\hline \multirow[t]{2}{*}{ Vote $_{i j t}$} & Vote cast by legislator $i$ from constituency $j$ in year $t$ & Up to 1996: ICPSR Study number 4 \\
\hline & Dummy equal to 1 if 'yea' and 0 if 'nay' & From 1997: http://www.voteview.com \\
\hline Senate $_{i t}$ & Dummy equal to 1 if legislator $i$ is a senator & As for Vote $_{i j t}$ \\
\hline Senate $_{i t}$ & Dummy equal to 1 if senator $i$ is in first two years of his or her term & As for Vote $_{i j t}$ \\
\hline Senate $2_{i t}$ & Dummy equal to 1 if senator $i$ is in middle two years of his or her term & As for Vote $_{i j t}$ \\
\hline Senate $3_{i t}$ & Dummy equal to 1 if senator $i$ is in last two years of his or her term & As for Vote $_{i j t}$ \\
\hline Democrat $_{i t}$ & Dummy equal to 1 if legislator $i$ is a Democrat & As for Vote $_{i j t}$ \\
\hline Party as President $i t$ & Dummy equal to 1 if legislator $i$ and President belong to same party in year $t$ & As for Vote $_{i j t}$ \\
\hline \multirow[t]{3}{*}{ Female $_{i}$} & Dummy equal to 1 if legislator $i$ is female & Up to 1996: ICPSR Study number 7803 \\
\hline & & From 1997 up to 2000: Swift et al. (2000) \\
\hline & & From 2001: Biographical Directory of U.S. Congress \\
\hline Age $_{i t}$ & Age of legislator $i$ & As for Female $i$ \\
\hline Population $_{j t}$ & Population of constituency $j$ (in millions) & U.S. Census Bureau \\
\hline 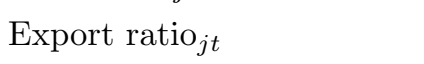 & $\frac{X_{j t}}{Y_{j t}}$ & County Business Patterns \\
\hline HHI exports $_{j t}$ & Herfindahl-Hirschman Index for export industries & County Business Patterns \\
\hline HHI imports ${ }_{j t}$ & Herfindahl-Hirschman Index for import industries & County Business Patterns \\
\hline High skill $_{j t}$ & Share of population above 25 years with at least a bachelor degree & U.S. Census Bureau \\
\hline Export $_{j t}$ & Dummy equal to 1 if Export ratio $_{j t}>1$ & As for Export ratio \\
\hline Labor contributions $_{i t}$ & Contributions received by senator $i$ from labor groups & Federal Election Commission \\
\hline Corporate contributions $_{i t}$ & Contributions received by senator $i$ from corporate groups & Federal Election Commission \\
\hline Safe $_{i t}$ & Dummy equal to 1 if Margin of victory ${ }_{i t} \geq 60$ percent & U.S. Office of the Clerk \\
\hline \multirow[t]{2}{*}{ Retiring $_{i t}$} & Dummy equal to 1 if senator $i$ retires (voluntarily leaves office) & Up to 2004: Overby and Bell (2004) \\
\hline & at the end of the mandate & From 2005: Biographical Directory of U.S. Congress \\
\hline Tenure $_{i t}$ & Length of service of senator $i$ up to year $t$ & As for Female $i$ \\
\hline Incumbent $_{i t}$ & Dummy equal to 1 if senator $i$ has been elected more than once & Biographical Directory of the United States Congress \\
\hline${\text { Appropriation } \text { committee }_{i t}}$ & Dummy equal to 1 if senator $i$ belongs to Appropriation committee & As for Female $_{i}$ \\
\hline Finance committee $_{i t}$ & Dummy equal to 1 if senator $i$ belongs to Finance committee & As for Female $_{i}$ \\
\hline Presidential aspirations $_{i t}$ & $\begin{array}{l}\text { Dummy equal to } 1 \text { if senator } i \text { ever participated in a presidential } \\
\text { primary after year } t\end{array}$ & Leip (2008) \\
\hline$\overline{Y j t}$ & Employees of constituency $j$ in import-competing industries & County Business Patterns \\
\hline$X_{j t}$ & Employees of constituency $j$ in export industries & County Business Patterns \\
\hline Import/export industries $t$ & Industries in which the U.S. is a net importer/exporter in year $t$ & $\begin{array}{l}\text { Feenstra (1996), Feenstra (1997), Feenstra et al. (2002) } \\
\text { and U.S. ITC, IMF BoP }\end{array}$ \\
\hline Margin of victory $_{i t}$ & Difference in votes shares between senator $i$ and runner-up in last election & U.S. Office of the Clerk \\
\hline
\end{tabular}


Table A-3: Descriptive statistics

\begin{tabular}{|c|c|c|c|c|c|c|}
\hline & \multicolumn{3}{|c|}{ House and Senate } & \multicolumn{3}{|c|}{ Senate } \\
\hline Variable & Observations & Mean & Std. dev. & Observations & Mean & Std. dev. \\
\hline Vote $_{i j t}$ & 7,664 & 0.687 & 0.464 & 1,254 & 0.750 & 0.433 \\
\hline Senate $_{i t}$ & 7,664 & 0.174 & 0.379 & & & \\
\hline Senate $1_{i t}$ & 7,664 & 0.058 & 0.234 & 1,254 & 0.325 & 0.449 \\
\hline Senate $2_{i t}$ & 7,664 & 0.059 & 0.235 & 1,254 & 0.337 & 0.473 \\
\hline Senate $3_{i t}$ & 7,664 & 0.057 & 0.231 & 1,254 & 0.338 & 0.473 \\
\hline Democrat $_{i}$ & 7,664 & 0.535 & 0.499 & 1,254 & 0.540 & 0.497 \\
\hline Party as President $i t$ & 7,664 & 0.509 & 0.500 & 1,254 & 0.498 & 0.500 \\
\hline Female $_{i}$ & 7,664 & 0.098 & 0.297 & 1,254 & 0.085 & 0.279 \\
\hline Age $_{i t}$ & 7,664 & 54.48 & 10.159 & 1,254 & 58.89 & 9.958 \\
\hline Population $_{j t}$ & 7,664 & 1.429 & 3.030 & 1,254 & 5.066 & 5.656 \\
\hline Export ratio $_{j t}$ & 7,664 & 0.442 & 0.540 & 1,254 & 0.528 & 0.550 \\
\hline HHI exports $_{j t}$ & 7,664 & 0.506 & 0.279 & 1,254 & 0.503 & 0.292 \\
\hline HHI imports $j t$ & 7,664 & 0.156 & 0.086 & 1,254 & 0.136 & 0.062 \\
\hline High skill $_{j t}$ & 7,661 & 0.194 & 0.084 & 1,254 & 0.192 & 0.056 \\
\hline Labor contributions $_{i t}$ & & & & 1,254 & 0.463 & 1.001 \\
\hline Corporate contributions $_{i t}$ & & & & 1,254 & 1.834 & 2.720 \\
\hline Safe $_{i t}$ & & & & 1,213 & 0.049 & 0.215 \\
\hline Retiring $_{i t}$ & & & & 1,254 & 0.043 & 0.203 \\
\hline Export $_{j t}$ & & & & 1,254 & 0.138 & 0.345 \\
\hline Tenure $_{i t}$ & & & & 1,254 & 12.033 & 9.426 \\
\hline Incumbent $_{i t}$ & & & & 1,254 & 0.632 & 0.476 \\
\hline${\text { Appropriation } \text { committee }_{i t}}$ & & & & 1,254 & 0.278 & 0.448 \\
\hline Finance committee $_{i t}$ & & & & 1,254 & 0.201 & 0.401 \\
\hline Presidential aspirations $_{i t}$ & & & & 1,254 & 0.105 & 0.307 \\
\hline
\end{tabular}

